\title{
PRECHODY DO DOSPELOSTI NA SLOVENSKU V PRIESTOROVEJ PERSPEKTÍVE PODLA SČÍTANIA OBYVATELOV 1991 A 2011
}

\author{
Branislav Šprocha* \\ * Centrum spoločenských a psychologických vied SAV, Šancová 56, 81105 Bratislava, \\ INFOSTAT - Výskumné demografické centrum, Leškova 16, Bratislava, \\ branislav.sprocha@gmail.com
}

\begin{abstract}
Transitions to adulthood in the spatial perspective in Slovakia according to the Population Censuses 1991 and 2011

The past quarter century has brought to Slovakia a number of significant, dynamic, dramatic and, in many ways, historically unique social transformations. Young generations in new social, political and economic conditions have changed several patterns of their behaviour. Transitions in the life cycles of young people have become more complex and less and less strictly predetermined and are affected by individualization and de-standardization. This is in sharp contrast to the relatively unified and standardized model of transitions in life trajectories from the period of the previous political regime in Slovakia. The main objective of the paper is to analyze the nature and changes of transitions to adulthood at a regional level. We are focusing on the timing of education termination, the transition to the labour market, the creation of one's own household and entry into marriage and parenthood.

Key words: transitions to adulthood, termination of education, transition to employment, residential autonomy, transition to marriage and parenthood, districts, Slovakia
\end{abstract}

\section{ÚVOD}

Obdobie posledných niečo vyše 25 rokov sa na Slovensku nesie v znamení významných, dynamicky prebiehajúcich, dramatických a v mnohých ohl'adoch historicky jedinečných spoločenských transformácií. İch hlavnými nositel'mi sú predovšetkým mladé generácie osôb, ktoré v novovznikajúcich spoločenských, politických a hospodárskych podmienkach menili a zmenili viaceré vzorce svojho správania. Z pohl'adu rodinného a reprodukčného správania sme predovšetkým svedkami poklesu intenzity plodnosti a sobášnosti (Potančoková et al. 2008 a Šprocha 2016), nárastu rizika rozvodu manželských zväzkov, odkladania vstupov do manželstva (Šprocha a Majo 2016), „starnutia“ materstva a rodičovstva (Potančoková 2009), rastúcej preferencie viac či menej stabilných rôznych foriem alternatívnych párových zväzkov (Mládek a Šročková 2004, Pilinská 2005 a Džambazovič a Šprocha 2017), zvyšovania intenzity plodnosti nevydatých (najmä slobodných) žien a s tým spojeného podielu detí narodených mimo manželstva (Vaňo, ed. 2012 a Šprocha 2015) a d'alších javov. Asi najvýraznejšie však charakter reprodukcie a rodinného správania ovplyvnili a ovplyvňujú zmeny v časovaní prechodov k manželstvu a rodičovstvu. Potvrdzujú to aj Lesthaeghe a Moors (2000), ktorí práve proces odkladania rodinných a reprodukčných zámerov považujú za jeden z najdôležitejších znakov postmoderných spoločností z pohl'adu druhej demografickej revolúcie. Tieto posuny je však potrebné vnímat' ako súčast' celého komplexu zmien v životných dráhach mladých dospelých (pozri napr. Chaloupková 2010 a Potančoková 2013), ku ktorým patrí aj odkladanie d’alších dôležitých prechodov v životných 
dráhach, ako je opustenie orientačnej rodiny a rezidenčná samostatnost’, ukončenie vzdelávania a prechod na trh práce a pod. Ako uvádza Lesthaeghe (1991 - 1992, p. 2) tranzície v životných cykloch mladých l’udí sa stávajú komplexnejšími a čoraz menej predstavujú striktne vopred nastavené vzorce správania. To je pomerne $\mathrm{v}$ ostrom kontraste $\mathrm{s}$ charakterom jednotlivých prechodov a ich nastavenia $\mathrm{z}$ obdobia minulého politického režimu na Slovensku. Je zrejmé, že predchádzajúci pomerne unifikovaný, štandardizovaný model nastavenia prechodov v životných dráhach konštituujúci sa počas minulého politického režimu (Potančoková 2013) prechádza v nových podmienkach individualizáciou a deštandardizáciou svojich sekvencií, typickou pre postmoderné spoločnosti (Lesthaeghe a Moors 2000 a Shanahan 2000).

Problematike prechodov do dospelosti bola na Slovensku zatial' venovaná len okrajová pozornost', pričom ešte horšia situácia je v prípade sledovania regionálnych rozdielov v týchto tranzíciách. Analyzované sú predovšetkým zmeny v časovaní rodinných a reprodukčných štartov (pozri napr. Jurčová ed. 2010 a Bleha et al. 2014), no d’alšie tranzície sú viac-menej prehliadané, a to aj napriek tomu, že ide o vel'mi dôležité posuny ovplyvňujúce nielen proces reprodukcie, formovanie vybraných populačných štruktúr, domácností, ale aj viaceré ekonomické procesy a samotný trh práce.

Hlavným ciel'om príspevku je analýza časovania hlavných prechodov do dospelosti u žien na Slovensku v regionálnom pohl'ade. Ženská populácia bola zvolená z viacerých dôvodov. Prvým je skutočnost', že z hl'adiska demografickej reprodukcie sú jednoznačne najdôležitejším faktorom nastavenia rodinných a reprodukčných dráh žien. Práve v ženskej populácii pritom identifikujeme najdynamickejšie zmeny vo vzdelanostných dráhach (napr. Bleha et al. 2014 a Majo a Šprocha 2016), ked' v najmladších generáciách už ženy dosahujú vyššie vzdelanie ako muži. V neposlednom rade u mužov nedisponujeme žiadnym zdrojom údajov umožňujúcim analyzovat' prechod k rodičovstvu, ktorý predstavuje jednu z najdôležitejších tranzícií na ceste k statusu dospelej osoby.

V súvislosti so smerovaním hlavného ciel'a sa zameriame nielen na identifikáciu prípadných priestorových rozdielov, ale pokúsime sa aj analyzovat' ich možné vývojové zmeny. Vzhl'adom na metodiku a použité vstupné údaje, budeme hodnotit' tieto prechody v dvoch časových sekvenciách. Prvou bude začiatok 90. rokov, ktoré ešte prezentujú predchádzajúci model fázovania prechodov do dospelosti podmienených v prevažnej miere špecifickými pomermi a faktormi pôsobiacimi počas minulého politického režimu. Druhým je obdobie približne dvoch desat'ročí po nastúpení hlbokých celospoločenských zmien na Slovensku.

\section{VSTUPNÉ ÚDAJE A POUŽITÁ METODIKA}

$\mathrm{V}$ súčasnosti nedisponujeme na Slovensku žiadnym rozsiahlym medzinárodne harmonizovaným výberovým zist'ovaním, ktoré by sa priamo zameriavalo na otázky prechodov do dospelosti. Obdobne nemáme žiadnu informáciu ani o domácom či súkromnom zist'ovaní, ktoré by sa snažilo problematiku rôznych prechodov v životných dráhach primárne zachytit'. V zahraničí sú pritom práve rôzne výberové zistovania základným zdrojom údajov pre tento typ analýz. Opierajú sa predovšetkým o otázky zamerané na súčasný, resp. minulý stav a časové aspekty jednotlivých prechodov, napr. v podobe zist'ovania rokov, v ktorých respondent/ka ukončil/a vzdelávanie, nastúpil/a do trvalého pracovného pomeru, vstúpil/a do manžel- 
stva alebo trvalého párového vzt’ahu, narodilo sa mu/jej prvé diet’a a pod. Zvolená metodika sa potom môže opierat' nielen o makroprístup, ale často sú analyzované životné trajektórie jednotlivcov aj na mikroúrovni. Vzhl'adom na neexistujúce informácie tohto typu v prípade Slovenska sa budeme musiet' opierat' o nepriamu makroanalýzu, pričom asi jediným vhodným zdrojom údajov pre všetky zvolené prechody do dospelosti sa ukazuje byt' sčítanie obyvatel'ov. Ked’že s výnimkou dátumu posledného manželstva nie sú jeho integrálnou súčast'ou údaje o časovaní d'alších prechodov, budeme musiet' ich časovanie opriet' o súhrnné nepriame indikátory založené na štrukturálnych charakteristikách zist’ovaných v jednotlivých cenzoch. V práci využívame výsledky sčítania l'udu, domov a bytov z marca roku 1991 a sčítania obyvatel'ov, domov a bytov z mája roku 2011. V oboch prípadoch sme disponovali primárnou databázou, ktorá nám umožňovala aplikovat' niektoré na vstupné údaje náročnejšie metodické postupy. Okrem toho bolo možné zachovat' rovnaké administratívne usporiadanie okresov (79 okresov). Základ pre našu analýzu predstavovali otázky týkajúce sa pohlavia, dátumu narodenia, z ktorého následne bol konštruovaný vek (v dokončených rokoch), miesta trvalého bydliska (obce), rodinného stavu (slobodná, vydatá, rozvedená a ovdovená), súčasnej ekonomickej aktivity ${ }^{1}$ a počtu živonarodených detín ${ }^{2}$.

$\mathrm{Na}$ hodnotenie časovania prechodov do manželského stavu u slobodných žien sme zvolili indikátor SMAM (Singulate Mean Age at Marriage), ktorý svojou povahou je akousi alternatívou priemerného veku pri prvom sobáši (pozri napr. Hajnal 1953). Ten je síce štandardne používaným indikátorom časovania sobášnosti slobodných, no na regionálnej úrovni na Slovensku ho možno konštruovat' až od prvej polovice 90. rokov. Okrem toho našou snahou bolo použit' metodicky totožné nástroje, a to nielen z časového, ale aj tematického hl'adiska. Základom pre konštrukciu SMAM je kombinačné triedenie údajov o ženách v jednotlivých okresoch Slovenska podl'a jednotiek veku a rodinného stavu. Samotný výpočet sa opiera o niekol'ko na seba nadväzujúcich krokov. V prvom sú identifikované vekovo špecifické podiely slobodných žien $\left(s_{x}^{s}\right)$. Následne sa snažíme vyjadrit’ počet človekorokov, ktoré žena prežije ako slobodná v jednotlivých vekových skupinách $\left(L_{x}^{s}\right)$ :

$$
L_{x}^{s}=s_{x}^{s} \cdot a_{x},
$$

kde $L_{x}^{s}$ je počet človekorokov, ktoré osoba vo veku $(x)$ prežije ako slobodná, $s_{x}^{s}$ je podiel slobodných osôb vo veku $(x)$ a $a_{x}$ je šírka vekového intervalu $(x)$.

\footnotetext{
${ }^{1}$ V sčítaní ludu 1991 sa zist'ovala „ekonomická aktivita“ pričom sa rozlišovali kategórie: ekonomicky činný (vrátane vojakov základnej služby, osoby vo väzbe, vo výkone trestu), žena na materskej dovolenke, hladajúci zamestnanie, pomáhajúci (bezplatne) $\mathrm{v}$ rodinnom hospodárstve, pracujúci a nepracujúci dôchodca, osoba s iným druhom príjmu (uved’te akým), žiak ZŠ, SOU, študent, žena v domácnosti, v zaopatrení rodiny a pod. V ostatnom sčítaní obyvatel'ov osoby vyplňali „súčasnú ekonomickú aktivitu“, a to: pracujúci (okrem dôchodcov), pracujúci dôchodca, osoba na materskej dovolenke, osoba na rodičovskej dovolenke, nezamestnaný, študent strednej školy, študent vysokej školy, osoba v domácnosti, dôchodca, príjemca kapitálových príjmov, diet’a do 16 rokov, iná.

${ }^{2} \mathrm{~V}$ roku 1991 ženy staršie 15 rokov mali uviest' ,počet všetkých živonarodených detí“ a v roku 2011 ,počet živonarodených detí“" (bezdetné zapíšu nulu).
} 
Pre celkový počet človekorokov, ktoré prežije osoba ako slobodná medzi vekom 16 a 50 rokov platí:

$$
L_{16 \rightarrow 50}^{s}=\sum_{x=16}^{50} L_{x}^{s} \text {. }
$$

V d'alšom kroku sa pre každú populáciu vyjadruje podiel žien, ktoré ani raz nevstúpili do manželstva do skončenia reprodukčného obdobia $\left(s_{50}^{s}\right)$, resp. aspoň raz do manželstva vstúpili $\left(s^{\check{s} \nu}{ }_{50}\right)$ a celkový počet človekorokov, ktoré prežili ako slobodné $\left(L_{50}^{s}\right)$ :

$$
L_{50}^{s}=50 \cdot s_{50}^{s} .
$$

Vzhl'adom na relatívne malé populácie, akými sú okresy na Slovensku, sme sa rozhodli, že $\left(s_{50}^{s}\right)$ a $\left(s^{\check{\nu}}{ }_{50}\right)$ odvodíme interpoláciou z pät'ročných vekových priemerov:

$$
S_{50}^{s}=\frac{\left(s_{45-49}^{s}+s_{50-54}^{s}\right)}{2} .
$$

V poslednom kroku sa výpočet $S M A M$ opiera o nasledujúci vzt’ah:

$$
S M A M_{16}^{49}=\frac{\left(16+L_{16 \dashv 99}^{s}-L_{50}^{s}\right)}{s_{50}^{\check{s}}}=\frac{\left(16+\sum_{16}^{49} s_{x}^{s} \cdot a_{x}=50 \cdot s_{50}^{s}\right)}{1-s_{50}^{s}} \text {. }
$$

Uvedomujeme si, že vzhl'adom na čoraz väčšiu obl'ubu nemanželských párových zväzkov by bolo vhodné pri analýze časovania tohto typu prechodov uvažovat' aj o ich vplyve, no v prípade Slovenska to znemožňuje nedostatok vhodných a metodicky porovnatel'ných vstupných údajov. Preto sme sa v našej práci obmedzili len na prechod k manželskému zväzku, ktorý aj napriek všetkým zmenám nad'alej predstavuje najdôležitejší priestor z pohl'adu rodinného a reprodukčného správania.

Časovanie prechodov $\mathrm{k}$ materstvu a rodičovstvu sme analyzovali prostredníctvom ukazovatel'a známeho pod označením $S M A F B$ (singulate mean age at first birth). Výpočet $S M A F B$ sa opiera o podiely bezdetných žien podl'a veku. V zmysle práce Bongaarts a Blanc (2015) môžeme konštrukciu $S M A F B$ definovat' ako:

$$
S M A F B_{0, t}^{x_{\max }}=\frac{\sum_{0}^{x_{\max }} p_{x, t}^{b e z}-p_{x_{\max , t}^{b e z}}^{b} \cdot x_{\max }}{1-p_{x_{\max , t}}^{b e z}}
$$

kde $p_{x, t}^{b e z}$ je podiel žien, ktoré sú bezdetné vo veku $(x)$ rokov v roku $(t)$ a $p_{x_{\max , t}}^{b e z}$ je podiel bezdetných žien vo veku $\left(x_{\max }\right)$ v roku $(t)$.

Z pohl'adu reprodukcie opätovne $\left(x_{\max }\right)$ stanovujeme na vek 50 rokov, pričom aj $\mathrm{v}$ tomto prípade podiel bezdetných $\mathrm{v}$ tomto vekovom intervale bol konštruovaný interpolačným prístupom z 5-ročných vekových priemerov:

$$
p_{50}^{b e z}=\frac{\left(p_{45-49}^{b e z}+p_{50-54}^{b e z}\right)}{2} .
$$


Uvedené vzt'ahy analogicky môžeme aplikovat' aj pri konštrukcii indikátorov vyjadrujúcich časovanie prechodov:

1) k rezidenčnej samostatnosti,

2) k aktívnej participácii na trhu práce,

3) k ukončenia vzdelávania.

Vo všetkých troch prípadoch pracujeme so štruktúrami žien v jednotlivých okresoch Slovenska získaných zo sčítaní 1991 a 2011. Pojem rezidenčná samostatnost' vnímame ako vytvorenie samostatnej cenzovej domácnosti ženou. Pod týmto pojmom chápeme situáciu, ked’ žena stojí na čele cenzovej domácnosti, alebo je vo vzt’ahu manželka, prípadne družka k jej prednostovi. Následne boli vypočítané vekovo-špecifické podiely žien deklarujúce v cenzoch, že stoja na čele domácnosti, resp. sú manželkami alebo družkami prednostov domácností $\left(s_{x, t}^{\text {hous }}\right)$. Z nich je potom úpravou predchádzajúceho vzt’ahu konštruovaný indikátor SMAFH (Singulate Mean Age at First Household):

$$
S_{M A F H}^{50}=\frac{\sum_{16, t}^{50} s_{x, t}^{\text {hous }}-s_{x_{0, t}}^{\text {hous }} \cdot 50}{1-s_{50, t}^{\text {hous }}} .
$$

Aktívna participácia na trhu práce je myslená v kontexte pracujúcich osôb. Znamená to, že do výpočtu vstupujú vekovo špecifické podiely žien, ktoré v čase sčítania uviedli, že sú pracujúcimi $\left(s_{x, t}^{p r a c}\right.$ ), resp. nepracujúcimi osobami. Potom bude indikátor $S M A F J$ (singulate mean age at first job):

$$
S M A F J_{16, t}^{35}=\frac{\sum_{16}^{35} s_{x, t}^{\text {prac }}-s_{x_{35, t}^{\text {prac }}} \cdot 35}{1-s_{35, t}^{\text {prac }}} \text {. }
$$

V prípade posledného indikátora (SMAEE - Singulate Mean Age at the End of Education) z výsledkov sčítaní 1991 a 2011 pre jednotlivé okresy Slovenska použijeme podiel žien, ktoré uviedli, že k rozhodujúcemu okamihu cenzu ešte študovali na strednej alebo vysokej škole $\left(s_{x, t}^{\text {stud }}\right)$ a analogicky potom platí:

$$
S M A E E_{16, t}^{35}=\frac{\sum_{16}^{35} s_{x, t}^{\text {stud }}-s_{x_{35, t}}^{\text {stud }} \cdot 35}{1-s_{35, t}^{\text {stud }}} .
$$

Uvedené prístupy v kombinácii so zdrojmi údajov majú niekol'ko výhod. Predovšetkým na rozdiel od výberových zist'ovaní pracujeme s úplným zist'ovaním, ktoré zachytáva celú populáciu Slovenska. Vd'aka tomu môžeme našu analýzu rozšírit' až na okresnú úroveň, čo v podstate žiadne výberové zist'ovanie na Slovensku neumožňuje. Okrem toho dostupnost' primárnych údajov zvyšuje šance na konštrukciu takých triedení, ktoré čo najviac zodpovedajú reálnej situácii z pohl'adu jednotlivých prechodov.

Negatíva spočívajú najmä $\mathrm{v}$ tom, že nemôžeme priamo analyzovat' časovanie prechodov, ked’že otázky na dátumy týchto tranzícií nie sú súčast'ou cenzov. Okrem toho je potrebné upozornit' na úskalia spojené s kvalitou a najmä úplnostou získaných údajov v spracovávaných sčítaniach. Najmä ostatný cenzus sa vyznačoval viacerými problémami pri zbere údajov, čo sa do určitej miery odzrkadlilo aj na 
vyššom zastúpení nezodpovedaných otázok ${ }^{3}$. Týkalo sa to aj nami sledovaných premenných. Existuje niekol'ko spôsobov, ako sa s takouto situáciou vyrovnat'. Zvolený bol prístup extrakcie záznamov, ktoré nedisponovali odpoved’ami na otázky týkajúce sa sledovaných životných tranzícií.

Ďalšie dôležité upozornenie sa týka charakteru použitého metodického prístupu. Sledované ukazovatele majú na prvý pohl'ad najväčšiu výpovednú silu v prípadoch, ked' spätná tranzícia nie je možná. Ide o vstup do prvého manželstva (po sobáši už nikdy nemôže byt' žena slobodnou) a narodenie prvého diet'at'a (už nikdy nebude môct' byt' klasifikovaná ako bezdetná v zmysle SODB). Ukončenie štúdia a založenie vlastnej domácnosti však nie je možné brat' ako ireverzibilné prechody, aj ked' môžeme predpokladat', že početnost' takýchto prípadov v sledovanom vekovom spektre nebude vel'ká. Ide o prípady, ked' žena začne opätovne študovat', alebo sa napríklad vráti do domácnosti svojich rodičov, nevytvára samostatnú cenzovú domácnost' a spoločne $\mathrm{s}$ nimi hospodári. Ešte výraznejšie to platí v prípade prechodov v rámci ekonomického postavenia, ked' v rámci životných cyklov a tiež vplyvom situácie miestneho trhu práce môže dochádzat' $\mathrm{k}$ viacerým rôznym prechodom medzi pracujúcou osobou a inými sledovanými skupinami ekonomickej aktivity. Ako sme už uviedli, sčítanie tieto spätné prechody neumožňuje identifikovat', čo do určitej miery môže ovplyvnit' výpovednú hodnotu konštruovaných indikátorov. Na druhej strane je však potrebné si uvedomit', že použité indikátory nesledujú prechody do dospelosti a ich načasovanie $\mathrm{v}$ dynamickom longitudinálnom pohl'ade, teda v pravom zmysle životných dráh, ale predstavujú skôr prierezový odhad poplatný zistenej štruktúre v momente sčítania. V podstate nám tak hovoria, aký počet rokov by žena prežila ako slobodná, bezdetná, bez vlastnej domácnosti, resp. v priemere v akom veku by došlo k ukončeniu štúdia, ako dlho by bola žena mimo pracovný proces, ak by sa v čase nemenila zistená štruktúra žien. Najmä z pohl'adu reverzibilných prechodov môžeme tak hovorit' o určitej snahe odhadnút' časový úsek, ktorý by žena prežila ako študentka, bez vlastnej domácnosti, resp. mimo pozície pracujúcej osoby, ak by sa v sledovanom vekovom spektre (a danom okrese) nezmenila daná populačná štruktúra. Tá samozrejme do značnej miery odráža všetky vonkajšie vplyvy, a to nielen z pohl'adu procesu vzdelávania, rodinného správania, ale aj charakteru miestneho trhu práce.

\section{PRECHODY DO DOSPELOSTI V MENIACICH SA PODMIENKACH NA SLOVENSKU PO ROKU 1989}

Vstup do dospelosti je spojený s nahromadením životných a najmä viacerých demografických prechodov (Rindfuss 1991). Ukončenie štúdia, vstup na pracovný trh, opustenie orientačnej rodiny, rezidenčná samostatnost', vstup do manželstva alebo stabilného partnerského zväzku a narodenie prvého diet’at'a predstavujú dôležité životné tranzície, ktoré sú vnímané ako súčast' širšieho procesu zahŕňajúceho prijatie súboru sociálne definovaných pozícií prepojených so sociálnym statusom dospelého (Modell et al. 1976, Chaloupková 2010 a Potančoková 2013). Prechod do dospelosti môžeme definovat’ ako sociálny konštrukt, prostredníctvom ktorého jedinec akceptuje sociálne úlohy spojené so štatútom dospelej osoby. Ide v podstate

\footnotetext{
${ }^{3}$ Podiel nevyplnených záznamov o počte živonarodených detí u žien vo veku 15 - 49 rokov v sčítaní 2011 dosiahol približne $11 \%$ (najčastejšie v mladom a vel'mi mladom veku). Podiel žien bez udania rodinného stavu v poslednom sčítaní dosiahol necelé $3 \%$. Ekonomická aktivita žien vo veku 16 - 35 rokov nebola vyplnená u približne $8 \%$ záznamov.
} 
o určitý súbor parciálnych prechodov, ktorých hlavným výsledkom je ekonomické osamostatnenie od orientačnej rodiny a založenie vlastnej prokreačnej rodiny (pozri napr. Modell et al. 1976, Marini 1984, Chaloupková 2010 a Potančoková 2013).

Viacerí autori (napr. Alan 1989, Škop 2006 a Potančoková 2013) poukazujú, že v minulom režime sa v bývalom Československu postupne vytvoril model štandardizovaných vstupov do dospelosti realizovaných v pomerne krátkom časovom rozpätí, pričom väčšina $\mathrm{z}$ nich bola realizovaná v približne rovnakom veku. Tento model bol podporený viacerými externými faktormi. V oblasti vzdelávania sa postupne vytvorili dva hlavné vzdelanostné modely s dôrazom na stredoškolské vzdelanie pri súčasnej obave o nadmernú ,produkciu“ vysokoškolsky vzdelaných osôb (Tuček et al. 2003). Orientácia na výrobné smery s kvótnym plánovaním prispela k vysokej regulácii a štandardizácii vzdelanostných dráh mladých l'udí. Rovnako centrálnemu plánovaniu podliehala aj tranzícia zo škôl do zamestnania (Simonová 2006). Málo efektívne pracovné postupy, extenzívne využívanie pracovných síl, viazanie značného počtu mladých mužov v armádnych a policajných zložkách znamenali trvalý nedostatok l'udských zdrojov. Navyše existovala zákonná povinnost' pracovat', čo spoločne vytváralo podmienky (takmer) úplnej zamestnanosti aj u mladých l'udí. Skorý vstup do manželstva bol pre slovenskú spoločnost' typickým už pred druhou svetovou vojnou (pozri Šprocha a Majo 2016). V období minulého politického režimu došlo ešte k zvýrazneniu tohto modelu (napr. Šprocha 2016), pričom vstup do manželstva zostal takmer univerzálnou tranzíciou, ktorú vo svojich životných dráhach absolvovalo viac ako 90 \% mužov a viac ako $95 \%$ žien (Šprocha 2016). Skorému vstupu do manželstva prispievali aj vysoké podiely predmanželských koncepcií, ktoré boli jednak výsledkom rozviazania normatívnych pohl'adov na predmanželský sex pri nedostatočných možnostiach aktívneho bránenia sa neželenému počatia (pozri Stloukal 1999 a Sobotka 2011), ako aj nastavenia celého komplexu štátnych pronatalitne zameraných politík zvýhodňujúcich v mnohých oblastiach mladé rodiny s det'mi. Predlžovanie materskej dovolenky spolu $\mathrm{s}$ jej platenou formou, prehlbovanie inštitucionálnej starostlivosti o deti $\mathrm{v}$ jasliach a materských školách, prednostné pridel'ovanie bytov mladým manželom s det'mi, ako aj rôzne formy novomanželských pôžičiek pre mladých prispievali k skorému načasovaniu vstupov do manželstva a rodičovstva. $Z$ pohl'adu rezidenčnej samostatnosti síce platilo zvýhodnenie mladých rodín s malými det'mi, no vel'mi dôležitým faktorom bola aj sféra pracovného zapojenia (prednostne robotnícke vrstvy), ako aj miesto bydliska a s tým spojené plánovanie bytovej výstavby. Nedostatok bytov a absencia vol'ného trhu s bytmi často znamenali pre mladé rodiny (aj s malými det'mi) nútené viacgeneračné súžitie s rodičmi (pozri Kučera 1994). S postupným rozmachom plánovanej centrálne riadenej i individuálnej bytovej výstavby sa však situácia zlepšila. Ako uvádzajú Škop (2006) s Kynčilovou (2009), rezidenčná samostatnost' nasledovala najčastejšie po ukončení denného štúdia a nástupe do prvého zamestnania, pričom bola úzko previazaná so začiatkom trvalého partnerského súžitia a so vstupom do manželstva.

V západných krajinách približne od konca 60. rokov (pozri Shanahan 2000 a Elzinga a Liefbroer 2007) a v postsocialistických krajinách po roku 1989 (Chaloupková 2010 a Potančoková 2013) dochádza k značnému predlžovaniu procesu vstupu do dospelosti a tým k odd'al'ovaniu jednotlivých čiastkových krokov a tiež $\mathrm{k}$ nárastu variability ich načasovania a usporiadania. Pád minulého režimu a diskontinuita životných podmienok priniesli na jednej strane celú škálu nových 
možností a príležitostí, no na druhej znamenali tiež nárast rizika nezamestnanosti, rastúce nároky na kvalitu l'udského kapitálu a flexibilitu pracovnej sily, pričom najmä mladí l'udia a predovšetkým absolventi sa dostávajú na trhu práce do problematickej situácie.

Proces vstupu do dospelosti sa čoraz viac komplikuje, životné dráhy sa stávajú turbulentnými, pričom čiastkové prechody do dospelosti nemusia byt' nezvratné, ako napr. rezidenčná samostatnost' a návrat $\mathrm{k}$ rodičom, vstup do partnerského zväzku a jeho rozpad, opakovaný návrat do školy (Aassve et al. 2007 a Chaloupková 2010). Mladí l'udia v postindustriálnych a postmoderných spoločnostiach čelia pomerne vysokej neistote a tá má za následok odkladanie dlhodobých záväzkov (Mills a Blossfeld 2005). Zvyšovanie investícií do l'udského kapitálu, predlžovanie vzdelávania sa deje v súvislosti s očakávaniami zlepšenia budúcej situácie na trhu práce, vyrovnania sa s ekonomickou neistotou a tiež využitia nových príležitostí vytvorených $\mathrm{v}$ priebehu ekonomickej transformácie. Dlhodobé záväzky vyvolané napríklad vstupom do manželstva, či rodičovstvom (v prípade Slovenska pozri napr. Šprocha 2014 a 2016), sú preto odkladané v nádeji, že neistota vzhl'adom na budúci vývoj bude časom klesat'. Môžeme tak, podobne ako Kohler et al. (2002), hovorit' o strategickom odkladaní. Situácia v tranzitívnych spoločnostiach však pravdepodobne nebola a nie je taká jednoznačná. Zvyšovanie l'udského kapitálu u mladých žien predstavuje istú formu redukcie neistoty, a preto $\mathrm{v}$ čase naplñania týchto investícií odkladajú manželstvo a rodičovstvo. Naopak, menej vzdelané ženy môžu spájat’ redukciu svojej neistoty so skorým vznikom partnerského zväzku a založením rodiny (Hašková 2006).

V predlžovaní prechodov do dospelosti vidí Arnett (2004) postupné formovanie špecifickej fázy v životných dráhach mladých l’udí (približne 18 - 25 rokov), ktoré označil ako vynárajúca sa dospelost' (emerging adulthood). V tomto období mladí l'udia odmietajú plánovat', prijímat' dlhodobé záväzky, je to čas značnej nestability, spontánneho správania bez zvažovania jeho dôsledkov (Chaloupková 2010).

Deštandardizácia životných trajektórií mladých žien z pohl'adu časovania a usporiadania jednotlivých tranzícií znamená, že tieto už nie sú v súlade s predchádzajúcimi normami ,riadneho“ usporiadania jednotlivých prechodov (Rindfuss 1991 a Corijn a Klijzing, eds. 2001). Jednotlivé tranzície však nie sú usporiadané a načasované náhodne, ale sú prepojené s vekovými normami určujúcimi ideálnu postupnost' a vhodnost' určitého veku na ich naplńanie (pozri napr. Settersten a Hägerstad 1996, Potančoková 2009 a Chaloupková 2010). Tie je možné podl’a Lashbrooka (2002) chápat' ako kolekciu sociálnych noriem reprezentujúcich pravidlá vekovo vhodného správania, časovania a postupnosti významných životných udalostí. Ak budeme abstrahovat' od formálnych vekových noriem daných zákonmi, neformálne vekové normy sú ukotvené v kultúrnom poriadku spoločnosti, kde majú podobu viac či menej všeobecne uznávaných orientačných pravidiel, čím ovplyvňujú individuálne správanie a sociálnu interakciu (Vidovićová a Gregorová 2007). Môžeme ich chápat' ako kolektívny konsenzus pri časovaní jednotlivých životných tranzícií a udalostí, prípadne ako predpisy a zákazy formované prostredníctvom rôznych mechanizmov sociálnej kontroly a podporované všeobecným súhlasom (Marini 1984).

Normatívne i štrukturálne teórie (bližšie pozri napr. Hašková 2006 a 2010) zmien rodinného a reprodukčného správania v súvislosti s odkladaním jednotlivých prechodov do dospelosti, s ich denštandardizáciou a pluralizáciou očakávajú, že ženy s vyšším l'udským a ekonomickým kapitálom, žijúce v centrálnych oblastiach, 
vyznačujúce sa vyššími príjmami budú v súvislosti s dlhodobými záväzkami pocit'ovat' väčšie náklady stratených príležitostí a častejšie budú inklinovat' $\mathrm{k}$ vol'be nových alternatívnych hodnôt a noriem (Lesthaeghe a Surkyn 1988). Súčasne s vyšším vzdelaním rastie aj emancipácia týchto žien, čo tiež vedie k odkladaniu dlhodobých záväzkov (Blossfeld 1995). Naopak, ženy s nižším vzdelaním, s nestabilným postavením na trhu práce alebo mimo formálny pracovný trh, vo vidieckom prostredí v marginalizovaných regiónoch budú pravdepodobne častejšie predstavovat' osoby orientujúce sa skôr na rodinu, ich prostredie bude viac vyznávat' tradičnejšie hodnoty a roly ženy (Hakim 2000 a 2003). Nemenej dôležitým faktorom môže byt' tiež štruktúra týchto žien podl'a etnicity (resp. národnosti) a náboženského vyznania (napr. Růžičková a Hamplová 2016 a Šprocha 2017).

\section{Ukončenie vzdelanostných dráh}

Celospoločenská transformácia, prechod z centrálne riadenej ekonomiky na trhovú, rastúci význam kvality l’udského kapitálu v kombinácii s dynamickým nárastom možností najmä terciárneho vzdelávania, problematická pozícia mladých l'udí do 25 rokov na trhu práce prispeli $\mathrm{k}$ historicky jedinečnému nárastu počtu a podielu absolventov vysokých škôl. Predlžovanie vzdelanostných dráh sa pritom týka najmä mladých generácií žien, ktoré v súčasnosti už dosahujú vyššie vzdelanie ako muži. Podl'a výsledkov posledného sčítania z roku 2011 v generáciách z prvej polovice 80 . rokov podiel žien s vysokoškolským vzdelaním už dosiahol hranicu 40 \%, kým podl'a sčítania v roku 1991 v kohortách ukončujúcich svoje vzdelanostné dráhy počas minulého politického režimu to zvyčajne nebolo ani $10 \%$.

Značná unifikácia vzdelanostných dráh s malými šancami na pokračovanie na terciárnom stupni je zjavná aj z priemerného veku žien pri ukončovaní vzdelávania. $\mathrm{V}$ takmer všetkých okresoch na začiatku 90. rokov dosahovali jeho hodnoty 18 19 rokov. Len v mestských okresoch Bratislavy a Košíc a v okrese Banská Bystrica prekračoval priemerný vek hodnotu 19 rokov. O dve intercenzálne obdobia neskôr sa situácia značne zmenila. V podstate vo všetkých okresoch je zjavný výrazný nárast priemerného veku pri ukončovaní vzdelávania. Z pohl'adu dynamiky najmenšie zmeny zaznamenávame v okresoch na juhu stredného a na východnom Slovensku (Lučenec, Vel'ký Krtíš, Rimavská Sobota, Revúca, Rožňava, Gelnica, Spišská Nová Ves, Košice-okolie, Trebišov, Medzilaborce a pod.), ako aj v mestských okresoch Bratislavy. Kým v prvom prípade je to skôr výsledok zaostávania týchto celkov $\mathrm{v}$ transformácii vzdelanostnej štruktúry smerom k terciárnemu vzdelaniu (pozri napr. Bleha et al. 2014), v prípade Bratislavy je to dôsledok značnej preferencie vysokoškolského vzdelania už na začiatku 90. rokov a tým aj vo všeobecnosti obmedzených možností d'alšieho zvyšovania podielu absolventiek vysokých škôl. Jednoznačne najdynamickejšie rástol priemerný vek pri ukončení vzdelávania na Považí (okresy Trenčín, Považská Bystrica a Púchov), v priestore okresov Žilina, Bytča, Námestovo, Tvrdošín, Dolný Kubín, Liptovský Mikuláš a Ružomberok, ako aj na východnom Slovensku v okresoch Košíc, v okrese Prešov, Svidník, Stropkov, Snina a Humenné. Na strednom Slovensku do tejto skupiny možno ešte zaradit’ okresy Banská Bystrica, Zvolen a Detva.

Aj vd'aka rozdielnej dynamike predlžovania štúdia došlo k značnej priestorovej diferenciácii hodnôt priemerného veku pri ukončovaní vzdelania. V podstate môžeme hovorit' o niekol'kých oblastiach vyznačujúcich sa najdlhšou participáciou na vzdelávaní. Ide najmä o Bratislavu so zázemím, okres Nitra a takmer súvislý pás územných celkov tiahnucich sa smerom na Považie až k okresu Liptovský Mikuláš 
(pozri obr. 2). K nim sa pripájajú okresy Banská Bystrica, Zvolen, Detva, Žiar nad Hronom a Žarnovica na strednom Slovensku. Na východe Slovenska okrem mestských okresov Košíc a okresu Prešov sú to najmä spomínané celky s dynamickým predlžovaním vzdelávania (Stropkov, Svidník, Humenné a Snina). Naopak, juh stredného Slovenska a viaceré okresy východného Slovenska (obr. 2) sa vyznačujú podpriemernými hodnotami sledovaného indikátora časovania ukončenia vzdelanostných dráh. Ako je zrejmé z práce Blehu et al. (2014), viaceré z týchto celkov sa vyznačujú vyšším zastúpením osôb so základným alebo stredoškolským vzdelaním bez maturity a naopak podpriemerným podielom vysokoškolákov. Tento stav úzko súvisí aj s národnostnou skladbou miestneho obyvatel'stva a predovšetkým vyšším podielom osôb rómskeho etnika vyznačujúceho sa vel'mi nízkym vzdelaním (pozri napr. Šprocha 2017).

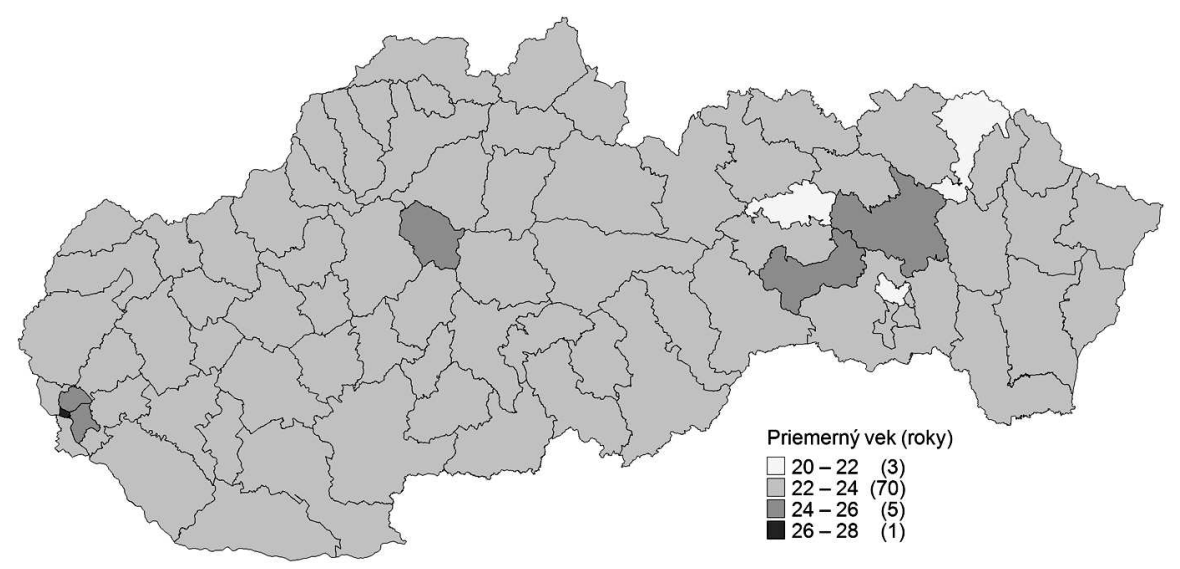

Obr. 1. Priemerný vek žien pri ukončení vzdelávania v okresoch Slovenska v roku 1991 Zdroj údajov: ŠÚ SR (1991), výpočty autor.

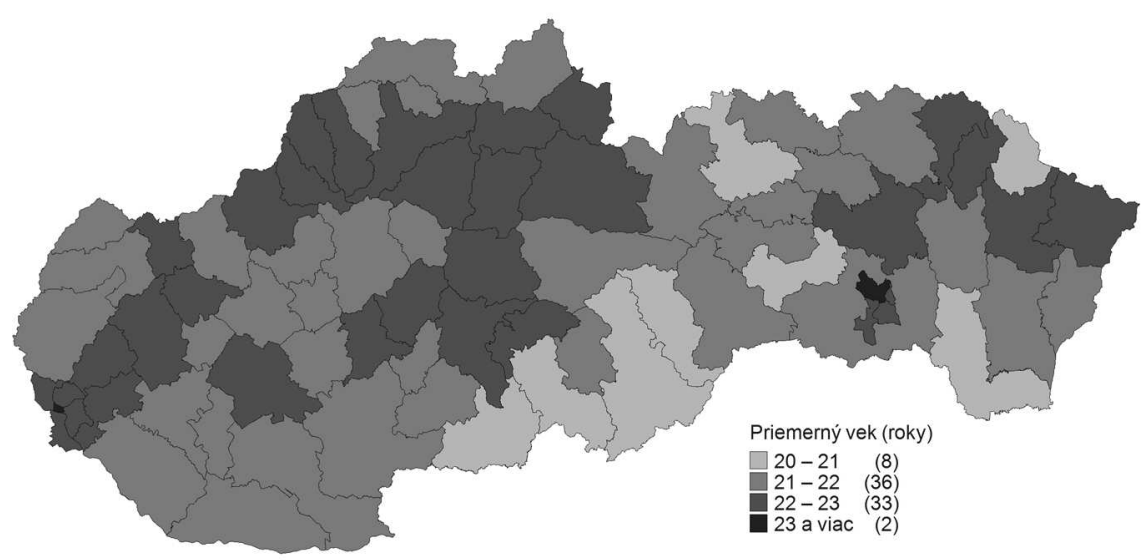

Obr. 2. Priemerný vek žien pri ukončení vzdelávania v okresoch Slovenska v roku 2011 Zdroj údajov: ŠÚ SR (2011), výpočty autor. 


\section{Prechod na trh práce}

Obdobie minulého režimu sa vyznačovalo povinnost'ou pracovat' a s tým súvisiacou absenciou rizika nezamestnanosti, minimálnou mierou vlastnej zodpovednosti, centrálnym riadením redistribúcie l'udských zdrojov do pracovného procesu, značnou platovou nivelizáciou a pod. Spoločne tieto faktory značne deformovali trh práce a tým aj prechody mladých l'udí do pracovného procesu. Tie boli úzko previazané s centrálnym plánovaním, čo znamenalo minimálne možnosti slobodnej vol'by a výberu povolania. Fluktuácia zamestnancov bola nežiaduca. Vzhl'adom na tieto skutočnosti a minimálne možnosti predlžovania vzdelávania na terciárnom stupni, vstup do pracovného procesu bol už v relatívne mladom veku. Potvrdzujú to aj výsledky zo začiatku 90. rokov, ked' síce už začalo dochádzat' k transformácii a prechodu od centrálne riadeného k trhovému hospodárstvu, no ich dosahy sa ešte významnejšie neprejavovali. Počet a podiel pracujúcich žien tak ovplyvňovalo najmä časovanie a početnost' tehotenstiev a následné čerpanie materskej a rodičovskej dovolenky. Efekt nezamestnanosti bol ešte zanedbatel'ný. Aj preto sa vo väčšine okresov Slovenska (obr. 3) priemerný vek pri vstupe do zamestnania pohyboval v rozpätí 19 - 21 rokov. Situácia sa však v nasledujúcich dvoch desat'ročiach značne zmenila, výsledkom čoho je aj určitá priestorová pluralizácia časovania prechodov do pracovného procesu. Je potrebné si uvedomit', že na tom, kedy v priemere žena začne pracovat', sa podiel'a nielen predlžovanie vzdelávania a z pohl'adu regionálnych rozdielov odlišné nastavenie dížky vzdelanostných dráh, ale aj miestne ekonomické podmienky (najmä možnosti zamestnania pre absolventov a mladých l'udí a s tým súvisiaca nezamestnanost'), ako aj nastavenie reprodukčných dráh. Okrem toho je potrebné si uvedomit', že najmä prechody medzi statusom pracujúcej či nezamestnanej osoby, ako aj ženy na materskej alebo rodičovskej dovolenke môžu prebiehat' v čase pomerne dynamicky a obojsmerne, čím sa tranzícia do pracovného procesu značne odlišuje najmä od sledovaných rodinných a reprodukčných prechodov. Na úzky vzt'ah medzi nezamestnanost'ou a vekom diet'at'a poukazuje napríklad štúdia Nývlta (2016).

Ako je zrejmé z obr. 4, skorší vstup do zamestnania v priemere viac nachádzame v niektorých okresoch na západe Slovenska. Rovnako neplatí, že najdlhšie mimo zamestnania by boli ženy v mestských okresoch Bratislavy a Košíc, prípadne $\mathrm{v}$ okresoch s najväčšími hospodárskymi centrami. Je potrebné si uvedomit', že aj ked' v týchto oblastiach síce ženy najdlhšie študujú, no relatívne nízka nezamestnanost' a vol'né pracovné miesta umožňujú skorší vstup do pracovného procesu. Nesmieme tiež prehliadnut' skutočnost', že tieto celky sa vyznačujú aj značným odkladaním materských a rodičovských rolí (pozri d’alej), čo sa tiež odzrkadl'uje na nižších hodnotách sledovaného indikátora. Väčšina okresov stredného Slovenska sa v podstate výraznejšie nelíši od celoslovenských hodnôt a priemerný vek pri vstupe do zamestnania sa pohybuje v rozpätí $24-25$ rokov. Nad hranicou 25 rokov sa nachádzajú predovšetkým okresy na východe Slovenska s výnimkou Košíc a pásu okresov od Prešova cez Vranov nad Topl'ou, Humenné a Sninu (obr. 4). Uvedený stav je výsledkom kombinácie spomínaných faktorov. Aj ked'v týchto okresoch ženy relatívne skoro ukončujú svoje vzdelanostné dráhy, horšie ekonomické pomery a s nimi spojená vysoká nezamestnanost' neumožňujú vyššiemu podielu mladých žien vstúpit’ do pracovného procesu. Navyše viaceré z týchto administratívnych celkov sa vyznačujú skorým začiatkom reprodukčných dráh, vyšším podielom detí narodených mimo manželstva, ako aj absenciou údajov o otcovi diet’at'a, čo môže predznamenávat' častejšie prípady osamelého rodičovstva. Ako poukazujú 
Němečková a Št’astná (2016), ide najmä o mladé ženy s nízkym vzdelaním, z menej rozvinutých regiónov, ktoré majú problém sa zamestnat', čím sa odd'al'uje aj ich samotná aktívna participácia na trhu práce.

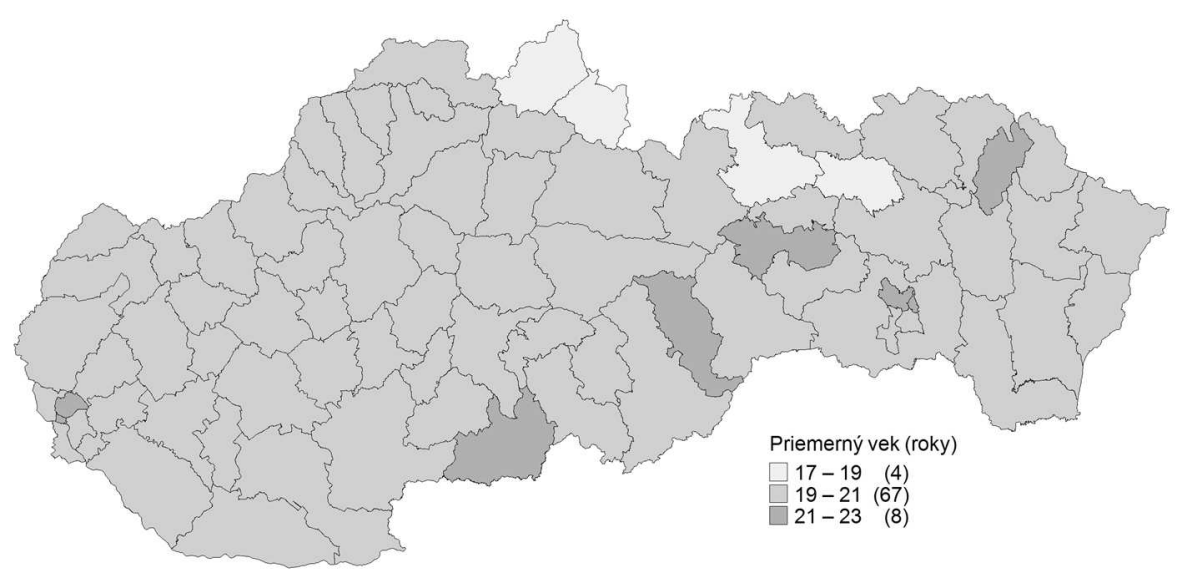

Obr. 3. Priemerný vek žien pri vstupe do zamestnania v okresoch Slovenska v roku 1991 Zdroj údajov: ŠÚ SR (1991), výpočty autor.

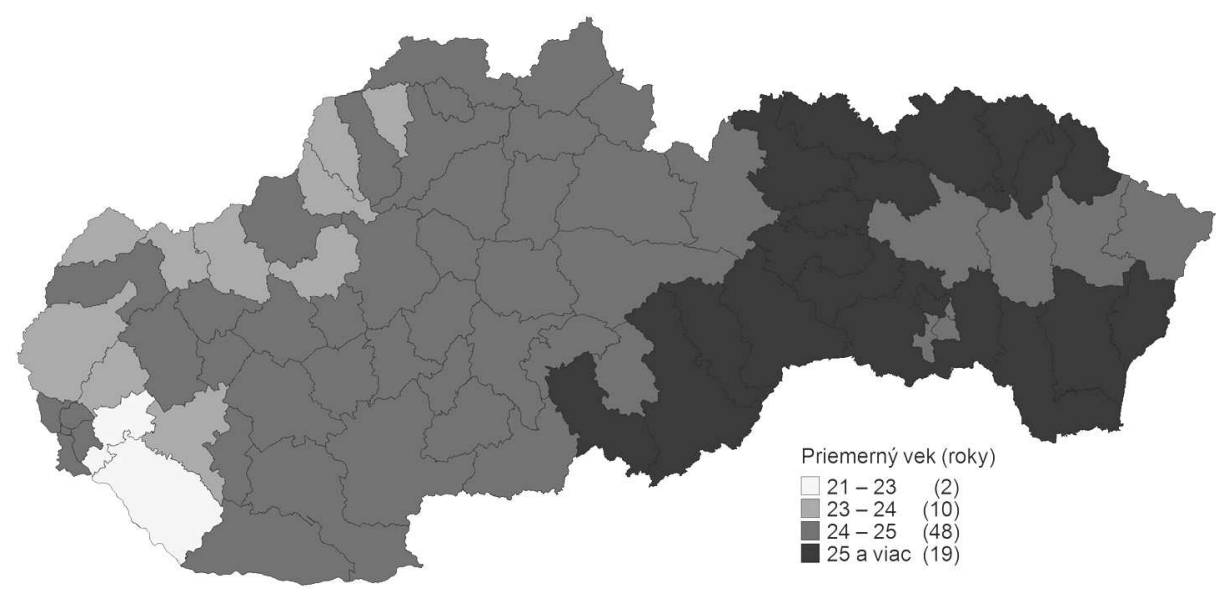

Obr. 4. Priemerný vek žien pri vstupe do zamestnania v okresoch Slovenska v roku 2011 Zdroj údajov: ŠÚ SR (2011), výpočty autor.

\section{Prechod k vlastnej domácnosti}

Kl'účovou tranzíciou v životných dráhach mladých l'udí a súčasne významným faktorom pre život $\mathrm{s}$ partnerom (manželom) a prechod $\mathrm{k}$ rodičovstvu je opustenie rodičovského domu a rezidenčná samostatnost'. V prípade krajín strednej a východnej Európy analýzy autorských kolektívov Corijn a Klijzing (2001) a Billari et al. (2001) poukazujú na pomerne dlhé spolužitie detí s rodičmi. Vo všeobecnosti je vnímané ako nedobrovol'né. Ako sme už ukázali, v minulosti bolo podmienené 
predovšetkým nedostatočnou bytovou výstavbou v kombinácii s rigidným centrálne organizovaným systémom redistribúcie, čo znamenalo, že bývanie bolo často dostupné len pre rodiny s det'mi. Súčasná bytová núdza je $\mathrm{v}$ intenciách cenovej nedostupnosti pre mladých l'udí pri takmer neexistujúcej výstavbe nájomných bytov. Spolu s expanziou terciárneho vzdelávania predstavujú dôležité faktory odkladania rezidenčnej samostatnosti. Výsledkom je, že vel'ká čast' prvých vzt'ahov začína pred tým, ako mladí l'udia opustia rodičovský dom. Medzi d'alšie faktory časovania rezidenčnej samostatnosti bývajú označované kultúrne rozdiely, dostupnost' bývania, špecifické inštitucionálne a ekonomické faktory ako zamestnanost', výška príjmu, priestorové rozmiestnenie terciárneho vzdelávania (Billari et al. 2001 a Aasve et al. 2002). Odkladanie samostatného bývania je v úzkej spojitosti s odkladaním formovania dlhodobých partnerských vzt'ahov a rodičovstva (Billari 2004).

Porovnanie obr. 5 a 6 potvrdzuje niekol'ko už deklarovaných informácií. Na začiatku 90. rokov na Slovensku existovali len pomerne malé regionálne rozdiely $\mathrm{v}$ časovaní prechodov k vlastnej cenzovej domácnosti. Nižší priemerný vek (do 22 rokov) nachádzame predovšetkým na južnom a strednom Slovensku a tiež na krajnom východe. Celkovo išlo o 28 okresov. Vo väčšine okresov (51), a to najmä na západnom a severnom Slovensku, sa prechod k samostatnej domácnosti realizoval $\mathrm{v}$ priemere o niečo neskôr ( $\mathrm{v}$ intervale $22-24$ rokov).

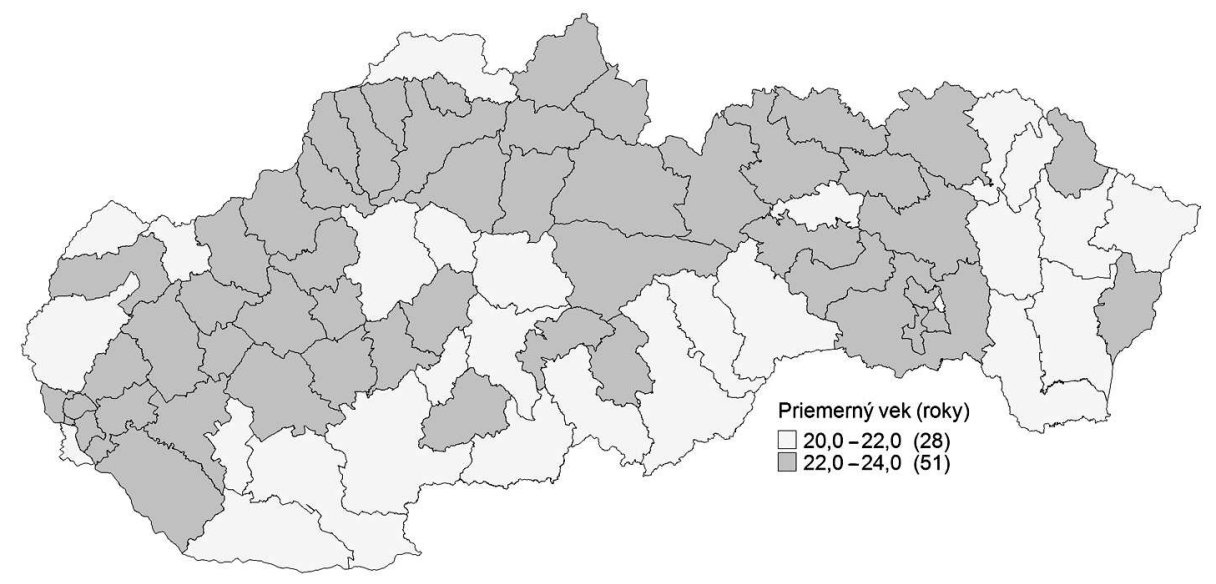

Obr. 5. Priemerný vek žien pri vytváraní samostatnej cenzovej domácnosti v okresoch Slovenska v roku 1991

Zdroj údajov: ŠÚ SR (1991), výpočty autor.

Počas nasledujúcich dvoch desat'ročí došlo k výraznej zmene časovania prechodov k samostatnej domácnosti. V podstate vo všetkých okresoch identifikujeme nárast hodnôt indikátora časovania tejto tranzície. Len v štyroch okresoch na juhu stredného Slovenska bol priemerný vek nad'alej nižší ako 24 rokov. Vo všeobecnosti práve južné časti stredného a východného Slovenska sa vyznačovali skorším začiatkom vzniku samostatných domácností. Najvyšší priemerný vek však, naopak, nie je spájaný s okresmi najväčších miest, ale ide predovšetkým o oblast' Považia a Ponitria (pozri obr. 6) a niektoré okresy na východe, kde sa priemerný vek žien pri vzniku samostatnej domácnosti už dostal nad hranicu 28 rokov. Zdá sa, že $\mathrm{v}$ týchto priestoroch sa kumulujú viaceré faktory pôsobiace v smere odkladania 
formovania samostatných domácností. Okrem dostupnosti bytov to môžu byt' najmä faktory spojené s ekonomickými javmi (zamestnanost' a výška mzdy), ale aj rodinným a reprodukčným správaním (intenzita a časovanie sobášnosti a rodenia prvých detí a rozvodovost'). Nemenej dôležité môžu byt' aj kultúrne zvyklosti v spojitosti s (ne-) dobrovol’ným viacgeneračným súžitím.

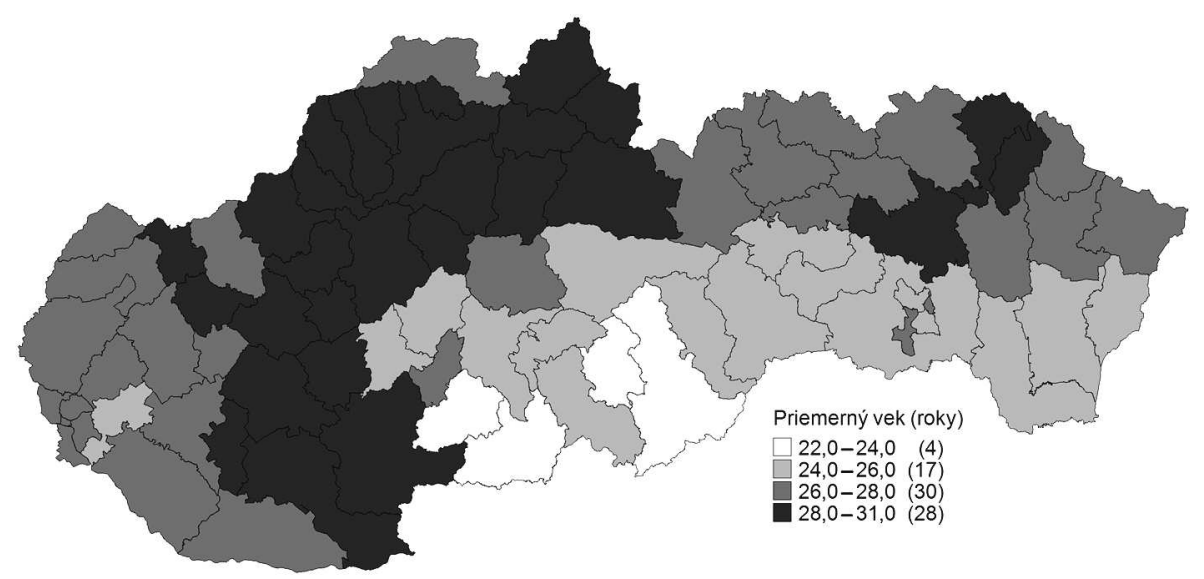

Obr. 6. Priemerný vek žien pri vytváraní samostatnej cenzovej domácnosti v okresoch Slovenska v roku 2011

Zdroj údajov: ŠÚ SR (2011), výpočty autor.

\section{Prechod k manželstvu}

Jedným $\mathrm{z}$ hlavných faktorov súčasných zmien $\mathrm{v}$ rodinnom správaní $\mathrm{v}$ európskom priestore je pokles intenzity sobášnosti, výrazné odkladanie manželstiev a partnerských spolužití, zvýrazňovanie nestability zväzkov a uvol’ňovanie prepojenia medzi manželstvom, intímnym životom a reprodukciou (Billari 2005, Prioux 2006 a Sobotka a Toulemon 2008). Ako sme už uviedli, Slovensko sa dlhodobo vyznačovalo vel'mi skorými vstupmi žien do manželstva, pričom len malá čast' z nich zostávala trvalo slobodná (Sprocha a Majo 2016). V poslednom štvrt'storočí však došlo $\mathrm{k}$ dramatickej a dynamicky prebiehajúcej transformácii tohto sobášneho modelu, pričom jedným z hlavných znakov je práve odkladanie rozhodnutia stat' sa manželkou. Okrem odkladania prvých manželstiev však musíme upozornit' aj na skutočnost', že pravdepodobne dochádza aj k zvyšovaniu zastúpenia tých žien, ktoré $\mathrm{z}$ rôznych dôvodov nevstupujú do manželstva. Kým proces odkladania vieme pomerne l'ahko empiricky dokázat' (napr. v podobe rastúceho priemerného veku pri prvom sobáši), problematika dlhodobej prípadne trvalej absencie manželstva $v$ životných dráhach mladých žien na Slovensku je zatial' $v$ podstate neriešená a nepoznáme žiadne štúdie ani dátové zdroje, ktoré by nám v tomto smere mohli pomôct'. Vel'mi podobná situácia je aj z pohl'adu nemanželských partnerských zväzkov. V súčasnosti disponujeme len obmedzenými informáciami o kohabitáciách a kohabitujúcich osobách (pozri napr. Mládek a Širočková 2004, Tydlitátová 2015, Džambazovič a Šprocha 2017 a Šprocha a Durček 2017), pričom údaje o časovaní ich vzniku absentujú. Rovnako nevieme nič o ich stabilite a d'alšom 
vývoji, a preto sa v d’alšej časti našej štúdie budeme zaoberat' len prechodom $\mathrm{k}$ manželstvu.

Aj v prípade vstupov do manželstva výsledky sčítania l’udu z roku 1991 potvrdili minimálne regionálne rozdiely a prevažujúce skoré načasovanie týchto prechodov. V 63 okresoch (zo 79) ženy vstupovali do manželstva vo veku $21-23$ rokov. V d'alších dvoch desat'ročiach sa situácia značne zmenila. Obdobne ako v predchádzajúcich prípadoch sme svedkami výrazného posunu prechodov k manželstvu do vyššieho veku. Najneskôr sa podl'a výsledkov sčítania obyvatel'ov v roku 2011 vydávajú ženy v mestských okresoch Bratislavy a Košíc a d’alej vo viacerých okresoch stredného Slovenska, kde hodnota $S M A M$ prekračuje už hranicu 30 rokov. Na druhej strane sever a viaceré okresy východného Slovenska (obr. 8) sa vyznačujú skorším vstupom do manželstva v rozpätí $26-28$ rokov.

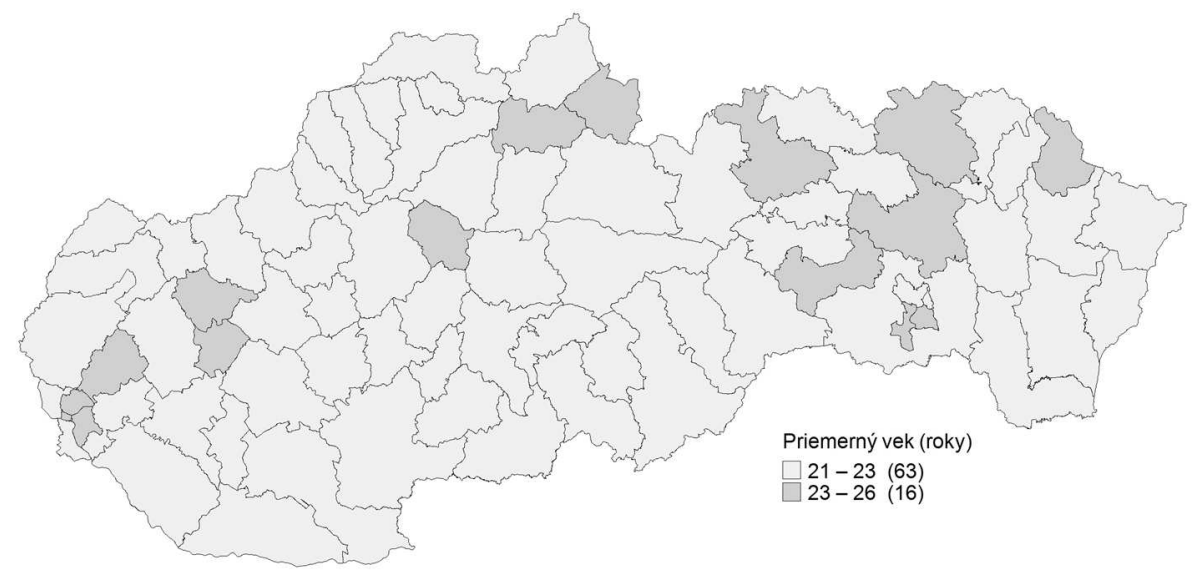

Obr. 7. Priemerný vek žien pri vstupe do manželstva v okresoch Slovenska v roku 1991 Zdroj údajov: ŠÚ SR (1991), výpočty autor.

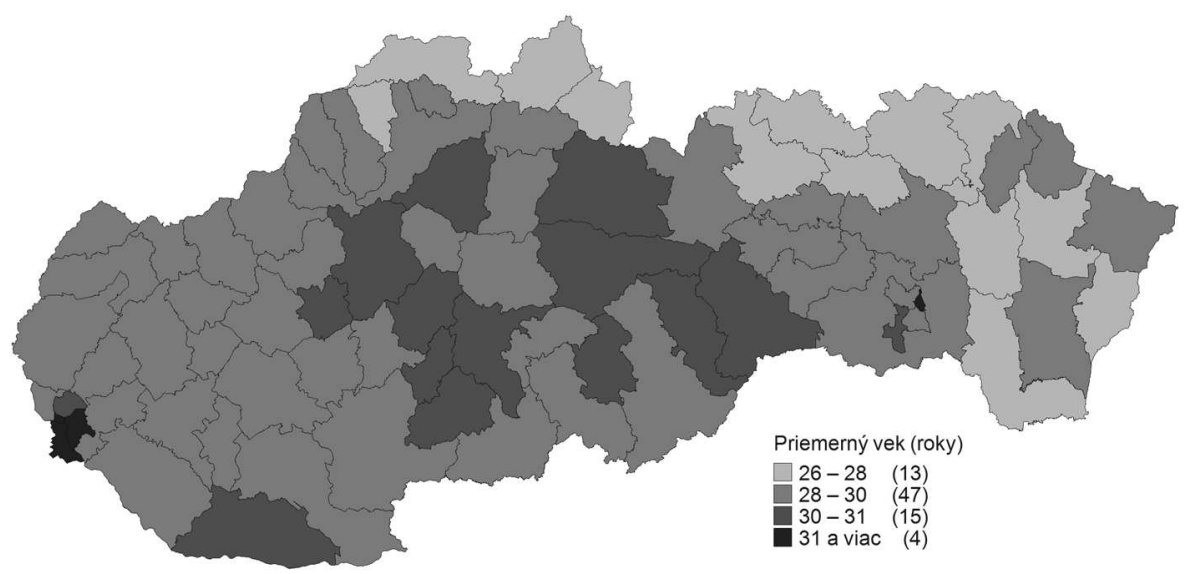

Obr. 8. Priemerný vek žien pri vstupe do manželstva v okresoch Slovenska v roku 2011 Zdroj údajov: ŠÚ SR (2011), výpočty autor. 


\section{Prechod $\mathrm{k}$ materstvu a rodičovstvu}

Materstvo a rodičovstvo sú často vnímané ako posledná udalost' na ceste k dospelosti. Na jej naplnenie je však v postmoderných spoločnostiach potrebná realizácia niektorých predchádzajúcich životných prechodov (ukončenie vzdelávania a prípravy na povolanie, stabilizácia na trhu práce, rezidenčná a ekonomická samostatnost' a pod.). Môžeme hovorit' o akýchsi postupných krokoch (sekvenciách), ktoré predstavujú vel'mi dôležitý faktor odkladania životných tranzícií s dlhodobými záväzkami, akými sú manželstvo a rodičovstvo.

Odkladanie materských štartov sa stalo v posledných dvoch dekádach univerzálnym javom vo všetkých európskych krajinách (Kohler et al. 2002, Sobotka 2004 a Frejka a Sardon 2004 a 2006). Na začiatku 21. storočia v podstate všetky európske spoločnosti majú skúsenost' s nástupom odkladania plodnosti, ktorý nad'alej pokračuje. Obzvlášt' intenzívne odkladanie pritom bolo pozorované najmä v krajinách strednej Európy, ktoré boli súčast’ou bývalého „,východného bloku“ (Frejka a Sobotka 2008). Ako vel'mi dôležitý faktor odkladania materských štartov sa ukazuje byt' výrazná expanzia terciárneho vzdelávania žien (van Bavel 2012). Podl'a výskumu Potančokovej (2009) vek, ked’ žena študuje, ešte spadá do obdobia mladosti a rola matky a manželky je v rozpore s očakávaniami spojenými so správaním mladých l'udí. Vzdelávanie, život v manželstve a rodičovské úlohy sú vnímané ako nezlučitel'né, alebo len t’ažko kombinovatel'né životné roly (napr. Rindfuss a Brauner-Otto 2008). Aj zahraničné výskumy potvrdzujú, že ženy s vyšším vzdelaním, s vyšším l'udským a ekonomickým kapitálom aktívne participujúce na trhu práce a s vyššími príjmami majú tendenciu odkladat' vstup do materstva častejšie (Bloom a Bennett 1990, Blossfeld 1995, Goldstein a Kenney 2001 a Jalovaara 2012).

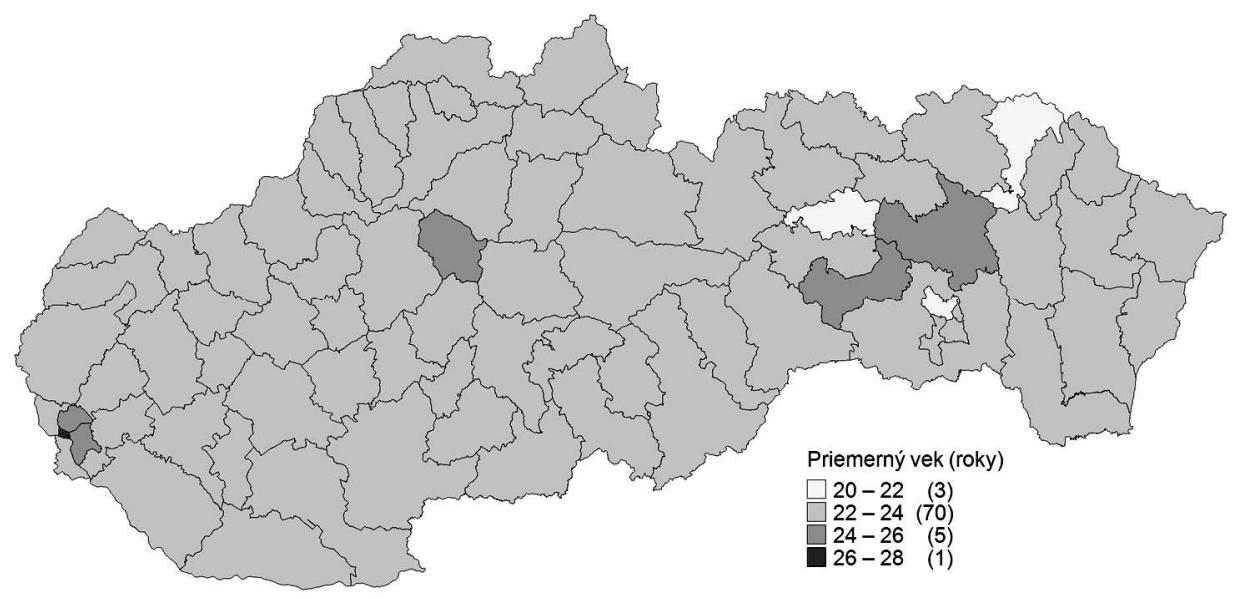

Obr. 9. Priemerný vek žien pri narodení prvého diet’at’a v okresoch Slovenska v roku 1991 Zdroj údajov: ŠÚ SR (1991), výpočty autor.

Začiatok 90. rokov sa niesol ešte $\mathrm{v}$ znamení minimálnych regionálnych rozdielov $\mathrm{v}$ časovaní prechodov $\mathrm{k}$ rodičovstvu. $\mathrm{V}$ podstate $\mathrm{s}$ výnimkou niektorých celkov sa tento prechod u žien odohrával vo veku $22-24$ rokov. Skoré a univerzálne nastavenie narodenia prvého diet'at'a však bolo vel'mi rýchlo opustené a v životných 
dráhach došlo nielen k výraznému odkladaniu, ale aj samotnej priestorovej pluralizácii. Potvrdzujú to aj výsledky posledného sčítania z roku 2011. Najdlhšie obdobie bezdetnosti nachádzame v mestských okresoch Bratislavy a Košíc, kde hodnoty ukazovatel'a $S M A F B$ prekračovali hranicu 30 rokov. S výnimkou južných a severných okresov v podstate celé západné a stredné Slovensko tvorilo priestor, kde sa ženy prvýkrát stávali matkami v priemere medzi 28. a 30. rokom života. Na druhej strane sa však potvrdilo, že juh, sever a väčšina východoslovenských okresov predstavuje priestor skoršieho časovania materských a rodičovských štartov.

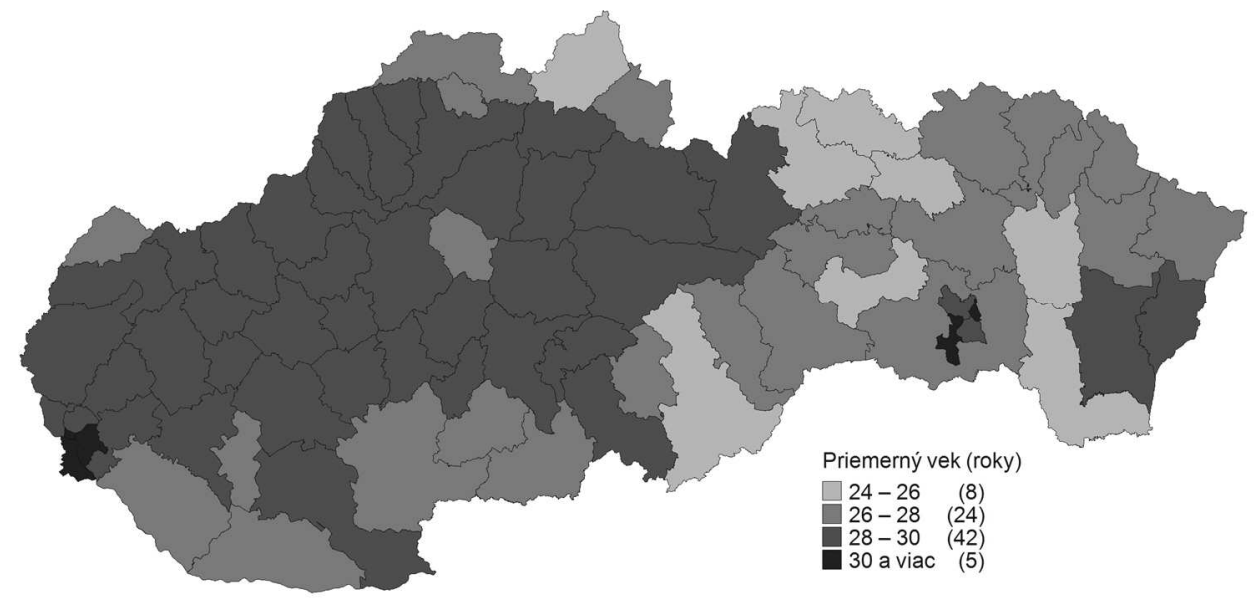

Obr. 10. Priemerný vek žien pri narodení prvého diet’at’a v okresoch Slovenska v roku 2011 Zdroj údajov: ŠÚ SR (2011), výpočty autor.

\section{ZÁVER}

Začiatok 90. rokov sa na Slovensku ešte niesol v znamení skorého načasovania jednotlivých prechodov do dospelosti. Len pomerne malé regionálne rozdiely potvrdzovali všeobecnú rozšírenost' tohto typu správania, ktoré sa u mladých žien konštituovalo ešte $\mathrm{v}$ špecifických podmienkach minulého režimu. Ak sa tiež pozrieme na časové rozloženie jednotlivých tranzícií, zistíme, že vo väčšine okresov mali stabilný priebeh. Najnižší priemerný vek dosahovali ženy pri ukončovaní štúdia. S určitým krátkym odstupom nasledovalo zamestnanie. O niečo dlhší časový úsek uplynul od vstupu do pracovného procesu po rezidenčnú samostatnost', pričom d'alšie prechody nasledovali už v pomerne rýchlom slede za sebou: manželstvo a narodenie prvého diet'at'a. Len v niektorých okresoch bol tento sled tranzícií narušený. Išlo najčastejšie o prípady, ked' priemerný vek pri narodení prvého diet'at’a bol o niečo nižší ako priemerný vek pri vstupe do prvého manželstva alebo uzavretie manželstva predchádzalo rezidenčnej samostatnosti. Celkovo však sledované prechody $\mathrm{k}$ dospelosti boli v priemere realizované v rozpätí relatívne krátkeho časového úseku, a to medzi 2,6 až 6,4 roka.

Obdobie posledných dvoch intercenzálnych období sa kryje s periódou najvýznamnejších celospoločenských transformácií, ktoré sa odrazili aj na časovaní analyzovaných prechodov do dospelosti. Okrem toho dochádza k významnému prehlbovaniu priestorových rozdielov a určitej diferenciácii Slovenska z pohl'adu toho, kedy dané tranzície do dospelosti najčastejšie ženy realizujú. Jedným z hlavných 
javov, ktorý ovplyvňuje načasovanie aj d’alších prechodov, je výrazné predlžovanie obdobia štúdia u žien. Potvrdilo sa, že tento trend zasiahol všetky okresy Slovenska, no zároveň je možné identifikovat' už existujúce pomerne značné regionálne rozdiely. Hlavnou zaostávajúcou oblast'ou sú predovšetkým okresy juhu stredného Slovenska a niektoré územné celky na východe. Opačná situácia je najmä v mestských okresoch Bratislavy a Košíc, ako aj vo viacerých okresoch západného a stredného Slovenska. Prechod na pracovný trh sa javí ako pomerne dynamická tranzícia podmienená viacerými d’alšími parciálnymi prechodmi, ako aj hospodárskou situáciou v okrese. Ukázalo sa, že vyššia miera nezamestnanosti, skorší začiatok materstva a rodičovstva (a pravdepodobne aj častejšie rodenie druhých a d'alších detí) vo viacerých okresoch východného Slovenska sú pravdepodobne príčinou toho, že je v tomto priestore aktívna participácia na trhu práce odsúvaná do vyššieho veku. Na druhej strane okresy západného Slovenska a tiež najväčších hospodárskych centier sa aj napriek dlhšiemu štúdiu vyznačujú skorším prechodom do zamestnania vzhl'adom na ich priaznivejšie hospodárske podmienky (a možnost' uplatnenia mladých osôb), ako aj výraznejšie odkladanie materstva a rodičovstva do vyššieho veku.

Naša analýza potvrdila aj odkladanie rezidenčnej samostatnosti a formovanie priestorových rozdielov z pohl'adu jej načasovania. Jednoznačne najskôr vytvárajú vlastnú domácnost' ženy na juhu stredného a východného Slovenska, teda v priestore, ktorý je spájaný aj so skorším časovaním d’alších rodinných a reprodukčných prechodov. Na druhej strane najdlhšie rezidenčnú samostatnost' odkladajú ženy vo viacerých okresoch západného a severu stredného Slovenska. Do tejto skupiny však nepatria okresy Bratislavy (a Košíc) a jej širšieho zázemia. Okresy dvoch najväčších miest Slovenska sa však jednoznačne vyznačujú najdlhším obdobím bezdetnosti a života žien mimo manželský zväzok. Práve v spojitosti s týmito dvomi prechodmi sa najvypuklejšie prejavujú formujúce sa regionálne rozdiely. Kým západné a značná čast' stredného Slovenska sa vyznačuje vysokými hodnotami priemerného veku pri prvom sobáši a pôrode, viaceré okresy severného, južného a východného Slovenska (s výnimkou Košíc) sú častejšie nositel'mi relatívne skorých vstupov do manželstva a narodení prvého diet'at'a. Ukazuje sa, že nielen prierezové indikátory časovania sobášnosti slobodných a rodenia prvých detí, ale aj štrukturálne ukazovatele reflektujúce dlhodobejšiu históriu sobášneho a reprodukčného správania v jednotlivých okresoch potvrdzujú nastúpený trend priestorovej diverzifikácie časovania týchto tranzícií.

Okrem nastúpených zmien načasovania, vzniku a prehlbovania regionálnych diferenciácií naša analýza tiež potvrdila určitú deštandardizáciu a predlžovanie intervalov medzi jednotlivými prechodmi do dospelosti. Kým na začiatku 90. rokov mali ešte značnú prevahu okresy s rovnakou súslednost’ou sledovaných prechodov (od ukončenia štúdia po narodenie prvého diet’at'a), podl'a posledného sčítania z roku 2011 je už v takmer každom okrese táto postupnost' narušená. Predovšetkým ide o výsledok výrazného rozpájania úzkeho vzt'ahu medzi plodnost'ou a životom v manželstve, ked' vo viacerých administratívnych celkoch priemerný vek pri prvom pôrode je nižší ako priemerný vek pri vstupe do manželstva. Novým javom je aj skoršie založenie vlastnej domácnosti v porovnaní s vekom vstupu do pracovného procesu. Tento jav nachádzame najmä v okresoch, pre ktoré je typický skorší vstup do materstva a rodičovstva, a ktoré majú horšie ekonomické podmienky pre zapojenie mladých žien na trh práce. Okrem toho naša analýza potvrdila aj predlžovanie obdobia medzi jednotlivými prechodmi. Minimálne časové rozpätie medzi 
prvým a posledným prechodom sa podl'a výsledkov sčítania v roku 2011 dostalo až k hranici 5,6 roku, kým maximálne dosahuje dokonca 11,5 roka. Pôvodná koncentrácia jednotlivých prechodov do úzkeho vekového intervalu sa zdá byt' minulost’ou a do popredia sa tak dostáva značná časová pluralizácia znamenajúca značné predlžovanie obdobia formovania statusu dospelej osoby.

Príspevok je čiastkovým výstupom vedeckého grantu VEGA 2/0057/17 - Najvyššie dosiahnuté vzdelanie a jeho vplyv na transformujúce sa rodinné a reprodukčné správanie žien na Slovensku.

Príloha:

Tab. 1. Časovanie analyzovaných prechodov do dospelosti $v$ okresoch Slovenska podl'a výsledkov sčítaní v rokoch 1991 a 2011

\begin{tabular}{|c|c|c|c|c|c|c|c|c|c|c|}
\hline \multirow{2}{*}{$\begin{array}{l}\text { IČ } \\
\text { okresu }\end{array}$} & \multicolumn{2}{|c|}{ Ukončenie štúdia } & \multicolumn{2}{|c|}{ Vstup do zamestnania } & \multicolumn{2}{|c|}{ Samostatná domácnost' } & \multicolumn{2}{|c|}{ Vstup do 1. manželstva } & \multicolumn{2}{|c|}{ Narodenie 1. diet'at'a } \\
\hline & 1991 & 2011 & 1991 & 2011 & 1991 & 2011 & 1991 & 2011 & 1991 & 2011 \\
\hline 101 & 20,5 & 23,3 & 21,4 & 24,6 & 23,4 & 27,5 & 25,7 & 34,8 & 26,3 & 32,9 \\
\hline 102 & 19,5 & 22,0 & 20,2 & 24,9 & 23,2 & 26,6 & 24,7 & 31,5 & 24,9 & 31,0 \\
\hline 103 & 19,7 & 22,2 & 21,5 & 24,8 & 23,2 & 26,7 & 23,9 & 30,1 & 24,4 & 29,7 \\
\hline 104 & 19,8 & 22,5 & 20,7 & 25,0 & 22,7 & 27,1 & 22,7 & 29,3 & 22,6 & 30,0 \\
\hline 105 & 19,1 & 22,3 & 20,2 & 24,9 & 22,0 & 27,9 & 22,8 & 31,2 & 22,0 & 32,2 \\
\hline 106 & 18,3 & 21,3 & 19,9 & 23,4 & 22,0 & 26,1 & 22,7 & 29,2 & 22,5 & 28,2 \\
\hline 107 & 18,8 & 22,2 & 20,0 & 23,2 & 23,1 & 26,8 & 23,1 & 28,7 & 23,7 & 28,6 \\
\hline 108 & 18,6 & 22,1 & 20,7 & 21,5 & 22,5 & 25,8 & 22,7 & 29,0 & 23,0 & 28,6 \\
\hline 201 & 18,1 & 21,6 & 19,4 & 22,9 & 22,1 & 27,5 & 22,4 & 30,0 & 22,5 & 27,9 \\
\hline 202 & 18,3 & 21,2 & 20,1 & 23,9 & 22,3 & 27,3 & 22,7 & 29,3 & 23,0 & 28,2 \\
\hline 203 & 18,4 & 21,8 & 19,8 & 24,9 & 23,0 & 27,8 & 23,2 & 29,2 & 23,7 & 28,7 \\
\hline 204 & 18,8 & 22,2 & 20,5 & 24,7 & 23,1 & 28,6 & 23,3 & 28,9 & 23,9 & 29,3 \\
\hline 205 & 18,3 & 21,3 & 20,0 & 24,9 & 22,2 & 27,4 & 22,3 & 29,2 & 22,7 & 28,7 \\
\hline 206 & 18,4 & 21,6 & 19,8 & 23,2 & 21,6 & 26,9 & 21,9 & 28,7 & 22,2 & 27,9 \\
\hline 207 & 18,8 & 22,2 & 20,4 & 24,9 & 23,1 & 27,7 & 22,4 & 29,7 & 23,0 & 29,6 \\
\hline 301 & 18,6 & 21,7 & 19,7 & 23,1 & 22,9 & 29,0 & 22,6 & 29,8 & 23,4 & 29,3 \\
\hline 302 & 18,8 & 22,0 & 20,2 & 23,4 & 22,2 & 28,5 & 22,9 & 29,9 & 23,9 & 29,8 \\
\hline 303 & 18,8 & 22,2 & 20,2 & 23,1 & 21,8 & 28,4 & 22,4 & 29,3 & 22,7 & 28,0 \\
\hline 304 & 18,7 & 21,8 & 20,4 & 23,5 & 22,3 & 27,8 & 22,5 & 29,8 & 23,0 & 29,1 \\
\hline 305 & 18,7 & 21,9 & 20,2 & 24,7 & 22,0 & 29,9 & 22,0 & 30,5 & 22,5 & 29,9 \\
\hline 306 & 18,7 & 22,5 & 20,2 & 24,6 & 22,7 & 28,7 & 22,0 & 29,9 & 22,7 & 29,0 \\
\hline 307 & 18,7 & 22,0 & 20,8 & 24,7 & 21,9 & 29,1 & 22,2 & 30,1 & 22,7 & 28,7 \\
\hline 308 & 18,5 & 22,0 & 20,4 & 23,7 & 22,7 & 29,7 & 22,9 & 28,9 & 23,7 & 28,8 \\
\hline 309 & 18,8 & 22,4 & 20,2 & 24,8 & 22,7 & 28,9 & 22,8 & 29,5 & 23,3 & 29,4 \\
\hline 401 & 18,3 & 21,5 & 19,7 & 24,6 & 21,7 & 27,9 & 21,9 & 30,0 & 22,5 & 27,6 \\
\hline 402 & 18,5 & 21,6 & 20,7 & 24,5 & 21,0 & 28,2 & 22,0 & 29,9 & 22,9 & 28,0 \\
\hline 403 & 18,9 & 22,3 & 20,6 & 24,6 & 22,2 & 28,4 & 22,3 & 29,3 & 23,1 & 28,4 \\
\hline 404 & 18,4 & 21,8 & 20,0 & 24,6 & 21,6 & 28,5 & 21,9 & 29,8 & 22,7 & 28,7 \\
\hline 405 & 18,5 & 21,4 & 20,1 & 25,0 & 22,0 & 28,3 & 21,9 & 29,8 & 22,1 & 27,5 \\
\hline 406 & 18,6 & 22,0 & 20,3 & 24,7 & 22,9 & 28,3 & 23,0 & 29,6 & 23,6 & 29,0 \\
\hline 407 & 18,6 & 21,9 & 20,3 & 24,8 & 22,1 & 30,2 & 22,5 & 29,6 & 23,0 & 29,4 \\
\hline 501 & 18,3 & 21,8 & 19,4 & 23,4 & 22,6 & 28,5 & 22,7 & 27,7 & 23,3 & 28,3 \\
\hline 502 & 18,3 & 21,6 & 20,1 & 24,8 & 21,1 & 27,8 & 22,5 & 27,6 & 23,2 & 26,8 \\
\hline 503 & 18,8 & 22,8 & 19,9 & 24,2 & 23,1 & 30,0 & 23,0 & 29,5 & 23,5 & 28,8 \\
\hline 504 & 18,5 & 21,8 & 20,8 & 24,8 & 22,4 & 28,2 & 22,6 & 28,7 & 23,5 & 26,9 \\
\hline 505 & 18,7 & 22,2 & 20,7 & 24,6 & 22,7 & 30,1 & 23,0 & 30,2 & 23,5 & 28,1 \\
\hline
\end{tabular}


pokračovanie tab. 1

\begin{tabular}{|c|c|c|c|c|c|c|c|c|c|c|}
\hline 506 & 19,0 & 22,4 & 20,7 & 24,7 & 22,2 & 29,7 & 22,9 & 30,3 & 23,1 & 28,7 \\
\hline 507 & 18,1 & 21,9 & 17,2 & 24,1 & 22,7 & 29,2 & 22,6 & 26,3 & 23,6 & 25,9 \\
\hline 508 & 18,6 & 22,6 & 20,1 & 24,4 & 22,3 & 29,5 & 22,6 & 28,9 & 23,2 & 28,4 \\
\hline 509 & 18,4 & 21,6 & 20,5 & 24,9 & 21,6 & 29,9 & 23,3 & 29,2 & 24,2 & 27,2 \\
\hline 510 & 18,7 & 22,1 & 18,8 & 24,7 & 23,1 & 29,6 & 23,9 & 26,9 & 23,9 & 26,8 \\
\hline 511 & 18,9 & 22,3 & 20,0 & 24,6 & 22,6 & 28,7 & 22,9 & 29,2 & 23,4 & 28,0 \\
\hline 601 & 19,1 & 22,6 & 20,9 & 24,7 & 21,8 & 26,9 & 22,5 & 30,0 & 23,7 & 29,2 \\
\hline 602 & 18,6 & 22,0 & 20,6 & 24,2 & 21,4 & 26,2 & 22,9 & 30,9 & 23,2 & 28,5 \\
\hline 603 & 18,4 & 21,6 & 20,8 & 24,1 & 22,3 & 24,2 & 22,9 & 30,5 & 22,8 & 29,2 \\
\hline 604 & 18,7 & 22,2 & 19,8 & 24,5 & 22,3 & 25,7 & 22,7 & 29,7 & 22,6 & 28,9 \\
\hline 605 & 18,1 & 21,6 & 20,4 & 24,2 & 22,5 & 22,3 & 22,4 & 30,1 & 22,5 & 27,6 \\
\hline 606 & 18,4 & 21,0 & 20,8 & 25,9 & 21,4 & 24,5 & 21,9 & 29,9 & 22,1 & 28,4 \\
\hline 607 & 18,2 & 21,3 & 19,7 & 24,1 & 22,3 & 23,5 & 22,6 & 30,4 & 23,9 & 27,4 \\
\hline 608 & 18,1 & 20,4 & 21,1 & 26,3 & 21,2 & 25,0 & 21,5 & 30,7 & 22,2 & 26,6 \\
\hline 609 & 18,1 & 20,2 & 20,8 & 25,2 & 21,2 & 23,0 & 21,6 & 29,9 & 22,4 & 25,4 \\
\hline 610 & 18,1 & 21,0 & 21,2 & 24,2 & 20,1 & 23,5 & 21,9 & 28,5 & 22,7 & 26,7 \\
\hline 611 & 19,0 & 22,6 & 20,8 & 24,4 & 21,9 & 24,8 & 22,7 & 30,7 & 23,0 & 29,6 \\
\hline 612 & 18,7 & 22,1 & 19,9 & 24,5 & 22,1 & 25,4 & 22,3 & 29,9 & 22,2 & 28,4 \\
\hline 613 & 18,8 & 22,2 & 20,4 & 24,3 & 22,1 & 24,9 & 22,8 & 30,9 & 23,4 & 29,3 \\
\hline 701 & 18,4 & 21,8 & 19,7 & 25,8 & 22,1 & 28,0 & 23,1 & 27,1 & 23,9 & 26,9 \\
\hline 702 & 18,7 & 22,2 & 20,9 & 24,2 & 21,8 & 27,6 & 22,9 & 27,4 & 23,9 & 27,9 \\
\hline 703 & 17,9 & 20,7 & 18,8 & 25,6 & 22,6 & 27,0 & 23,2 & 26,8 & 23,5 & 25,0 \\
\hline 704 & 18,3 & 21,7 & 20,0 & 25,5 & 21,7 & 27,1 & 21,7 & 28,4 & 20,4 & 26,5 \\
\hline 705 & 18,4 & 20,9 & 20,8 & 25,2 & 22,3 & 27,8 & 23,3 & 29,9 & 23,2 & 27,1 \\
\hline 706 & 18,7 & 21,8 & 20,3 & 24,3 & 22,4 & 27,8 & 22,7 & 29,6 & 23,1 & 28,6 \\
\hline 707 & 18,7 & 22,3 & 20,0 & 24,1 & 22,7 & 28,1 & 23,4 & 28,3 & 24,1 & 27,7 \\
\hline 708 & 18,2 & 21,3 & 18,5 & 25,5 & 22,5 & 27,2 & 22,9 & 27,4 & 23,5 & 25,3 \\
\hline 709 & 18,6 & 22,1 & 20,7 & 24,2 & 21,8 & 27,6 & 22,5 & 28,2 & 23,6 & 26,7 \\
\hline 710 & 18,2 & 21,8 & 19,7 & 25,7 & 22,5 & 27,5 & 22,6 & 27,7 & 23,0 & 26,0 \\
\hline 711 & 18,6 & 22,2 & 21,3 & 25,8 & 21,9 & 28,6 & 22,8 & 28,8 & 22,3 & 27,2 \\
\hline 712 & 18,5 & 22,1 & 19,2 & 25,9 & 21,8 & 28,3 & 22,0 & 27,5 & 21,9 & 26,8 \\
\hline 713 & 18,3 & 21,2 & 20,8 & 24,1 & 21,7 & 27,6 & 22,2 & 27,2 & 23,2 & 25,3 \\
\hline 801 & 18,1 & 20,8 & 20,1 & 25,4 & 23,0 & 25,5 & 23,5 & 29,0 & 24,1 & 24,5 \\
\hline 802 & 19,5 & 23,2 & 21,3 & 25,9 & 22,1 & 25,7 & 22,0 & 29,1 & 21,8 & 28,5 \\
\hline 803 & 19,0 & 22,4 & 20,3 & 24,2 & 22,4 & 26,2 & 23,3 & 30,7 & 23,3 & 30,7 \\
\hline 804 & 18,7 & 22,8 & 21,2 & 24,1 & 21,7 & 26,3 & 22,4 & 31,3 & 22,7 & 31,1 \\
\hline 805 & 19,2 & 22,8 & 20,2 & 24,3 & 22,8 & 25,3 & 23,5 & 28,7 & 23,6 & 29,6 \\
\hline 806 & 18,1 & 21,0 & 20,9 & 25,7 & 22,1 & 24,3 & 22,5 & 28,5 & 23,1 & 27,6 \\
\hline 807 & 18,5 & 21,2 & 20,3 & 25,5 & 21,7 & 25,6 & 22,4 & 29,0 & 23,0 & 28,1 \\
\hline 808 & 18,3 & 21,1 & 21,0 & 25,3 & 22,0 & 24,9 & 22,2 & 30,3 & 22,5 & 27,3 \\
\hline
\end{tabular}

Zdroj údajov: ŠÚ SR (1991 a 2011), výpočty autor.

\section{LITERATÚRA}

AASSVE, A., BILlARI, F. C., MAZZUCO, S., ONGARO, F. (2002). Leaving home: a comparative analysis of ECHP data. Journal of European Social Policy, 12, 259-276.

AASVE, A., BILLARI, F., PICCARETA, R. (2007). Strings of adulthood: a sequence analysis of young British women's work-family trajectories. European Journal of Population, 23, 369-388.

ALAN, J. (1989). Etapy života očima sociologie. Praha (Panorama). 
ARNETT, J. (2004). Emerging adulthood. The winding road from late teens through the twenties. Oxford (Oxford University Press).

BILLARI, F. (2004). Becoming an adult in Europe: a macro(/micro)-demographic perspective. Demographic Research S3, 2, 15-44.

BILLARI, F. (2005) Partnership, childbearing and parenting: trends of the 1990s. In UNECE/UNFPA, eds. The new demographic regime. Population challenges and policy responses. Geneva (United Nations), pp. 63-94.

BILLARI, F., PHILIPOV, D., BAIZÁN, P. (2001). Leaving home in Europe: the experience of cohorts born around 1960. International Journal of Population Geography, 7, 339-356.

BLEHA, B., VAŇO, B., BAČÍK, V., eds. (2014). Demografický atlas Slovenska. Bratislava (Geo-Grafika).

BLOOM, D. E., BENNETT, N. (1990). Modelling American marriage patterns. Journal of the American Statistical Association, 85, 1009-1017.

BLOSSFELD, H. P. (1995). The new role of women: family formation in modern societies. London (Westview Press).

BONGAARTS, J., BLANC, A. K. (2015). Estimating the current mean age of mothers at the birth of their first child from household surveys. Population and Health Metrics, 13, 25.

CORIJN, M., KLIJZING, E., eds. (2001). Transition to adulthood in Europe. Dordrecht (Kluwer Academic Publishers).

DŽAMBAZOVIČ, R., ŠPROCHA, B. (2017). Kto žije v kohabitáciách na Slovensku? Intenzita vytvárania a charakteristiky kohabitujúcich osôb podla výsledkov Sčítania obyvatel'ov, domov a bytov 2011. Sociológia, 49, 369-404.

ELZINGA, C. H., LIEFBROER, A. C. (2007). De-standardization of family-life trajectories of young adults: a cross national comparison using sequence analysis. European Journal of Population, 23, 225-250.

FREJKA, T., SARDON, J. P. (2004). Childbearing trends and prospects in low-fertility countries: a cohort analysis. Dordrecht (Kluwer Academic Publishers).

FREJKA, T., SARDON, J. P. (2006). First birth trends in developed countries: persisting parenthood postponement. Demographic Research, 15(6), 147-180.

FREJKA, T., SOBOTKA, T. (2008). Overview chapter 1: fertility in Europe: diverse, delayed and below replacement. In Frejka, T. Sobotka, T., Hoem, J. M. Toulemon, L., eds. Childbearing trends and policies in Europe. Demographic Research, 19, pp. 15-46.

GOLDSTEIN, J. R., KENNEY, C. T. (2001). Marriage delayed or marriage forgone? New cohort forecasts of first marriage for U.S. women. A merican Sociological Review, 66, 506-519.

HAJNAL, J. (1953). Age at marriage and proportions marrying. Journal of Population Studies, 7, 115-136.

HAKIM, C. (2000) Work-lifestyle choices in the 21st century: Preference theory. Oxford (Oxford University Press).

HAKIM, K. (2003). A new approach to explaining fertility patterns: preference theory. Population and Development Review, 29, 349-374.

HAŠKOVÁ, H. (2006). Zkoumání bezdětnosti, jejího růstu a s ním souvisejících sociodemografických jevů v české společnosti v kontextu zemí střední a východní Evropy. In Hašková, H., ed. Fenomén bezdětnosti v sociologické a demografické perspektivě. Praha (Sociologický ústav AV ČR), pp. 22-58.

HAŠKOVÁ, H. (2010). Fenomén bezdétnosti. Praha (SLON).

CHALOUPKOVÁ, J. (2010). Proměny rodinných a profesních starti̊. Praha (Sociologický ústav AV ČR).

JALOVAARA, M. (2012). Socio-economic resources and first-union formation in Finland, cohorts born 1969 - 1981. Population Studies, 66, 69-85.

JURČOVÁ, D., ed. (2010). Populačný vývoj v okresoch Slovenskej republiky 2009. Bratislava (INFOSTAT). 
KOHLER, H. P., BILLARI, F., ORTEGA, J. A. (2002). The emergence of lowest-low fertility in Europe during the 1990s. Population and Development Review, 28, 641-680.

KUČERA, M. (1994). Populace České republiky 1918 - 1991. Praha (Česká demografická Společnost a Sociologický ústav Akademie věd ČR).

KYNČILOVÁ, L. (2009). Leaving parental home in selected Central European countries. Acta Universitatis Carolinae. Geographica, 1-2, 103-123.

LASHBROOK, J. (2002). Age norms. In Ekerdt, D. J., ed. Encyklopedia of Aging. Vol. 1. New York (Macmillan Reference), pp. 40-43.

LESTHAEGHE, R. (1991-92). The Second Demographic Transition in Western Countries: An Interpretation. IPD-Working Paper. Brussel (Centrum Sociologie, Vrije Universiteit Brussel).

LESTHAEGHE, R., MOORS, G. (2000). Recent trends in fertility and household formation in the industrialized world. Review of Population and Social Policy, 9, 121-170.

LESTHAEGHE, R., J. SURKYN. (1988). Cultural dynamics and economic theories of fertility change. Population and Development Review, 14, 1-45.

MAJO, J., ŠPROCHA, B. (2016). Storočie populačného vývoja Slovenska II.: populačné štruktúry. Bratislava (INFOSTAT).

MARINI, M. M. (1984). Age and sequencing norms in transition to adulthood. Social Forces, 63, 229-244.

MILLS, M., BLOSSFELD, H. P. (2005). Globalization, uncertainty and the early life course: a theorethical framework. In Mills, M., Blossfeld, H. P., Klijzing, E., Kurz, K., eds. Globalization, uncertainty and youth in society. London, New York (Routledge), pp. 1-24.

MLADEK, J., ŠIROČKOVÁ, J. (2004). Kohabitácie ako jedna z foriem partnerského spolužitia obyvatel'stva Slovenska. Sociológia, 36, 423-454.

MODELL, J., FURSTENBERG, F. F., HERSHBERG, T. (1976). Social change and transitions to adulthood in historical perspective. Journal of Family History, 1, 7-32.

NĚMEČKOVÁ, M., ŠŤASTNÁ, A. (2016). Determinanty nevyplnění údajů o otci do hlášení o narození. Demografie, 58, 249-262.

NÝVLT, O. (2016). Ženy v rodinných domácnostech s dětmi a jejich postavení na trhu práce v kontextu vývoje po roce 1989. Demografie, 58, 197-212.

PILINSKÁ, V. (2005). Demografická charakteristika rodiny na Slovensku. Bratislava (INFOSTAT).

POTANČOKOVÁ, M. (2013). Rodina a životné dráhy mladých dospelých. In Krivý, V., ed. Ako sa mení slovenská spoločnost'. Bratislava (Sociologický ústav SAV), pp. 89127.

POTANČOKOVÁ, M. (2009). Odkladanie materstva do vyššieho veku na Slovensku vo svetle štatistických a kvalitatívnych dát. In Bleha, B., ed. Populačný vývoj Slovenska na prelome tisicroči kontinuita či nová éra? Bratislava (Geo-grafika), pp. 39-61.

POTANČOKOVÁ, M., VAŇO, B., PILINSKÁ, V., JURČOVÁ, D. (2008). Slovakia: fertility between tradition and modernity. In Frejka, T., Sobotka, T., Hoem, J. M., Toulemon, L., eds. Childbearing trends and policies in Europe. Demographic Research, 19, Special collection, 7, pp. 973-1018.

PRIOUX, F. (2006). Cohabitation, marriage and separation: contrasts in Europe. Population \&Societies, 422, 1-4.

RINDFUSS, R. (1991). The young adult years: diversity, structural change, and fertility. Demography, 28, 493-512.

RINDFUSS, R., BRAUNER-OTTO, S. (2008). Institutions and the transition to adulthood: implications for fertility tempo in low fertility settings. Vienna Yearbook of Population Research, 57-87.

RŮŽIČKOVÁ, M., HAMPLOVÁ, D. (2016). Analýza vztahu náboženského vyznání a plodnosti ve sčítání lidu 2011 (se zařazením vlivu dalších proměnných). Demografie, $58,213-229$. 
SETTERSTEN, Jr. R. A., HÄGESTAD, G. O. (1996). What's the latest? Cultural age deadlines for family transitions. The Gerontologists, 36, 178-188.

SHANAHAN, M. J. (2000). Pathways to adulthood in changing societies: variability and mechanisms in life course perspective. Annual Review of Sociology, 26, 667-692.

SIMONOVÁ, N. (2006). Vzdělanostní nerovnosti a vzdělanostní mobilita v období socialismu. In Matejů, P., Straková, J., eds. (Ne)rovné šance na vzdélání. Vzdělanostní nerovnosti v České republice. Praha (Academia), pp. 62-91.

SOBOTKA, T. (2004). Postponement of childbearing and low fertility in Europe. Amsterdam (Dutch University Press).

SOBOTKA, T. (2011). Fertility in Central and Eastern Europe after 1989. Collapse and gradual recovery. Historical Social Research (Special issue Fertility in the 20th Century: trends, policies, theories, discourses), 36, 246-296.

SOBOTKA, T., TOULEMON, L. (2008). Overview chapter 4: Changing family and partnership behaviour: common trends and persistent diversity across Europe. Demographic Research, 19(6), 85-138.

STLOUKAL, L. (1999). Understanding the "abortion culture" in Central and Eastern Europe. In David, H. P., ed. From abortion to contraception: a resource to public policies and reproductive behaviour in Central and Eastern Europe from 1917 to the present. Connecticut (Greenwood Press), pp. 23-37.

ŠKOP, M. (2006). Odchod žen od rodičủ v České republice. In Hamplová, D., Šalamounová, P., Samanová, G., eds. Životní cyklus. Sociologické a demografické perspektivy. Praha (Sociologický ústav AV ČR), pp. 46-59.

ŠPROCHA, B. (2014). Odkladanie a rekuperácia plodnosti v kohortnej perspektíve v Českej republike a na Slovensku. Demografie, 56, 219-233.

ŠPROCHA, B. (2015). Narodení mimo manželstva a plodnost' nevydatých žien na Slo-vensku. Demografie, 57, 127-143.

ŠPROCHA, B. (2016). Transformácia sobášnosti slobodných v Českej a Slovenskej republike v prierezovom a kohortnom pohl'ade. Demografie, 58, 237-238.

ŠPROCHA, B. (2017). Rómska populácia na Slovensku a kohortná plodnost' rómskych žien podl'a výsledkov sčítania obyvatel'ov, domov a bytov 2011. Demografie, 59, 118131.

ŠPROCHA, B., MAJO, J. (2016). Storočie populačného vývoja Slovenska I.: demografické procesy. Bratislava (INFOSTAT).

ŠPROCHA, B., ĎURČEK, P. (2017). Hodnotenie priestorových aspektov kohabitácií na Slovensku. Geographia Cassoviensis, 11, 70-88.

ŠÚ SR (1991). Sčitanie l’udu, domov a bytov 1991. Primárna databáza. Bratislava (Štatistický úrad SR).

ŠÚ SR (2011). Sč́tanie obyvatel’ov, domov a bytov 2011. Primárna databáza. Bratislava (Štatistický úrad SR).

TUCEK, J. a kol. (2003). Dynamika české společnosti a osudy lidí na přelomu tisíciletí. Praha (SLON).

TYDLITÁTOVÁ, G. (2015) Vol'ba nezosobášeného spolužitia v podmienkach sociálneho a situačného tlaku. Sociológia, 47, 91-216.

Van BAVEL, J. (2012). The reversal of gender inequality in education, union formation and fertility in Europe. Vienna Yearbook of Population Research, 10, 127-154.

VAŇO, B., ed. (2012). Populačný vývoj v Slovenskej republike v roku 2011. Bratislava (INFOSTAT).

VIDOVIĆOVÁ, L., GREGOROVÁ, E. (2007). Věkové normy v sociologické perspektivě. Sociální studia, 1-2, 201-217. 


\author{
Branislav $\check{S}$ procha
}

\title{
TRANSITIONS TO ADULTHOOD IN THE SPATIAL PERSPECTIVE IN SLOVAKIA ACCORDING TO THE POPULATION CENSUSES 1991 AND 2011
}

The period after 1989 brought a number of important changes to Slovakia, which reflected also the character and the timing of transitions to adulthood. New social, political and economic conditions of the younger generation have changed its behavioural patterns. It appears that the postponement of family and reproductive intentions is one of the most important features of post-modern societies. These shifts, however, must be seen as part of the whole complex of changes in young adult lives. This group also includes the postponement of residential autonomy, the termination of education and the transition to the labour market.

The main aim of this paper is to analyze the transitions to adulthood in Slovakia in a regional context. We are focusing on the early 1990s, which have not been affected by transformational changes and contemporary features. Based on the analyses, the timing indicators for transitions to adulthood are constructed from the 1991 and 2011 Population and Household Census results.

Prolongation of study period was confirmed in all districts. At least dynamically, this process is taking place in the south of Central Slovakia and some districts in the east. The opposite situation is mainly in economic centres and in several districts of Western and Central Slovakia. The transition to employment is conditioned by several further transitions as well as the economic situation of the region. The longest delays in entering women into the labour market were identified in several districts of Eastern Slovakia. This is related in particular to the earlier timing of maternity and parenthood as well as to the generally unfavourable economic situation. On the other hand, the districts of Western Slovakia, as well as the largest economic centres, despite their longer studies, are characterized by an earlier transition to employment due to their more favourable economic conditions (and the possibility of employing young people), as well as a more pronounced postponement of maternity and parenthood.

Women in the south of Central and Eastern Slovakia create their own household at the youngest mean age. This is in close interconnection with the earlier timing of other family and reproductive transitions. On the other hand, the residence autonomy is the longest postponed by women in several districts of western and Northern Central Slovakia. However, the districts of Bratislava (and Košice) and its wider background do not belong to this group.

The districts of the Western and large parts of Central Slovakia are characterized by the longest periods of childlessness and the life of women outside marriage. On the other hand, several districts of Northern, Southern and Eastern Slovakia (with the exception of Košice city) are characterized by relatively early marital and parental starts.

The results of our analysis confirmed that at the beginning of the 1990s, adult transitions followed a certain uniform standardized sequential model, which differed only marginally from a spatial point of view. Under the new conditions, however, there has been an unambiguous individualization and de-standardization of these transitions. We can identify in all regions their postponement to an older age and also the extension of the time required to complete all transitions to adulthood. In addition, it has been confirmed that there is considerable divergence between the regions in terms of the timing of the transitions to adulthood. 